\title{
Ultra-structural mapping of sugarcane bagasse after oxalic acid fiber expansion (OAFEX) and ethanol production by Candida shehatae and Saccharomyces cerevisiae
}

\author{
Anuj K Chandel ${ }^{1 *}$, Felipe F A Antunes ${ }^{1}$, Virgilio Anjos ${ }^{2}$, Maria J V Bell ${ }^{2}$, Leonarde N Rodrigues ${ }^{2}$, Om V Singh ${ }^{3}$, \\ Carlos A Rosa ${ }^{4}$, Fernando C Pagnocca ${ }^{5}$ and Silvio S da Silva ${ }^{*}$
}

\begin{abstract}
Background: Diminishing supplies of fossil fuels and oil spills are rousing to explore the alternative sources of energy that can be produced from non-food/feed-based substrates. Due to its abundance, sugarcane bagasse (SB) could be a model substrate for the second-generation biofuel cellulosic ethanol. However, the efficient bioconversion of SB remains a challenge for the commercial production of cellulosic ethanol. We hypothesized that oxalic-acid-mediated thermochemical pretreatment (OAFEX) would overcome the native recalcitrance of SB by enhancing the cellulase amenability toward the embedded cellulosic microfibrils.

Results: OAFEX treatment revealed the solubilization of hemicellulose releasing sugars (12.56 g/l xylose and $1.85 \mathrm{~g} / \mathrm{l}$ glucose), leaving cellulignin in an accessible form for enzymatic hydrolysis. The highest hydrolytic efficiency (66.51\%) of cellulignin was achieved by enzymatic hydrolysis (Celluclast $1.5 \mathrm{~L}$ and Novozym 188). The ultrastructure characterization of SB using scanning electron microscopy (SEM), atomic force microscopy (AFM), Raman spectroscopy, Fourier transformnear infrared spectroscopy (FT-NIR), Fourier transform infrared spectroscopy (FTIR), and X-ray diffraction (XRD) revealed structural differences before and after OAFEX treatment with enzymatic hydrolysis. Furthermore, fermentation mediated by C. shehatae UFMG HM52.2 and S. cerevisiae 174 showed fuel ethanol production from detoxified acid $(3.2 \mathrm{~g} / \mathrm{l}$, yield $0.353 \mathrm{~g} / \mathrm{g} ; 0.52 \mathrm{~g} / \mathrm{l}$, yield, $0.246 \mathrm{~g} / \mathrm{g}$ ) and enzymatic hydrolysates ( $4.83 \mathrm{~g} / \mathrm{l}$, yield, $0.28 \mathrm{~g} / \mathrm{g} ; 6.6 \mathrm{~g} / \mathrm{l}$, yield $0.46 \mathrm{~g} / \mathrm{g}$ ).
\end{abstract}

Conclusions: OAFEX treatment revealed marked hemicellulose degradation, improving the cellulases' ability to access the cellulignin and release fermentable sugars from the pretreated substrate. The ultrastructure of SB after OAFEX and enzymatic hydrolysis of cellulignin established thorough insights at the molecular level.

\section{Background}

Multidimensional applications have increased the demand for fossil fuels, sending disturbing signals regarding low levels of crude oil underground and the burden on aging refineries [1]. Recent developments have explored marginally meaningful alternatives to fossil fuels such as bioethanol using corn grains or sugarcane juice as substrates, which would result in tremendous price hikes for basic food commodities around the world [2]. However,

\footnotetext{
* Correspondence: anuj.kumar.chandel@gmail.com; silvio@debiq.eel.usp.br 'Department of Biotechnology, University of São Paulo, School of Engineering of Lorena, Estrada Municipal do Campinho- Caixa, Postal 116 12.602.810, Lorena/SP, Brazil

Full list of author information is available at the end of the article
}

bioethanol produced from sustainable feedstocks such as lignocellulosics has drawn worldwide attention as a legitimate alternative to gasoline. The development of green gasoline or ethanol from abundantly available cellulosic materials in nature is gaining significant momentum as a sustainable mitigation strategy [3]. As an alternative to fossil and food-based fuels, cellulosic ethanol offers near-term environmental sustainability benefits. However, the selection of a raw substrate and its efficient utilization are critical steps in the process of economization. Brazil and India are the largest producers of sugarcane, with an annual production of about 650 and $350 \mathrm{MMT} /$ year respectively [4], able to supply sugarcane bagasse (SB) in abundance round the year. 
SB consists of crystalline cellulose nanofibrils embedded in an amorphous matrix of cross-linked lignin and hemicelluloses that impairs enzyme and microbial accessibility [5]. Structural changes in the cellular components of SB have been studied after pretreatment with formic acid [6], sono-assisted acid hydrolysis [7], and sequential acid-base [8] methodologies. However, visual characterizations of cellular components elucidating the hemicellulose degradation and delocalization of lignin after oxalic acid fiber expansion (OAFEX) pretreatment have yet to be performed. Cell wall anatomy of SB and macroscopic/microscopic barriers for cellulase-mediated saccharification reveal that cell wall hydrolysis encompasses several orders of magnitude $\left(10^{0}-10^{-9}\right.$ meters $[9,10]$.

Oxalic acid (OA) is a strong dicarboxylic acid with higher catalytic efficiency than the sulfuric acid, and acts primarily upon hemicellulose. Pretreatment with OA leaves cellulignin in a fragile form, making it amenable to concerted cellulolytic enzyme action on cellulose, which yields glucose. The current pretreatment methodologies used to degrade the holocellulosic (cellulose + hemicellulose) fraction of the plant cell wall have economic and environmental limitations. However, OAFEX has been found to be an efficient pretreatment strategy for hemicellulose removal from giant reed [11], Saccharum spontaneum [12], corn-cobs [13], and wood chips [14]. Therefore, a comprehensive structural analysis of the nanoscale architecture of OAFEX-treated cell walls in tandem with molecular changes will assist to explore the fundamental mechanisms of biomass recalcitrance.

The fermentation of pentose and hexose sugars present in lignocellulose hydrolysate is important to produce "economic ethanol" $[15,16]$. Candida shehatae, native xylose-fermenting yeast, has shown the capability to utilize pentose sugars efficiently for ethanol production $[17,18]$. The microorganism Saccharomyces cerevisiae is a perennial choice for bioethanol production from glucose-rich cellulosic hydrolysates [19]. We attempted to pretreat SB using OA followed by enzymatic hydrolysis. The released sugars (12.56 g/l xylose and $1.85 \mathrm{~g} / \mathrm{l}$ glucose) were than subjected to ethanol fermentation using $C$. shehatae UFMG HM 52.2 and S. cerevisiae 174 in batch fermentation. A multiscale structural analysis of native, OAFEX-treated and enzyme-digested SB was performed using scanning electron microscopy (SEM), atomic force microscopy (AFM), X-ray diffraction (XRD), Raman spectroscopy, near infrared spectroscopy (NIR), and Fourier transform infrared (FTIR) analysis, and revealed the structural differences before and after OAFEX treatment and enzymatic hydrolysis.

\section{Results and discussion}

The abundance availability of SB as substrate can be used for fuel ethanol production without jeopardizing food and feed production. SB is rich in lignocellulosics contained (\% d. wt.): cellulose 45.0, hemicellulose 25.8, lignin 19.1, structural ash 1.0, extractive 9.1 [20]. The holocellulosic (hemicellulose + cellulose) content of SB (circa 70\%) is fairly comparable with other lignocellulosic materials studied for ethanol production, such as wheat straw (54\%), birch (73\%), spruce (63.2\%) (11), corn stover (59.9\%), and poplar (58.2\%) [21]. Biomass recalcitrance and efficient sugar conversion into ethanol are among the key hindrances to ethanol production that are preventing biorefineries from taking a central role in the energy sector.

\section{OAFEX treatment of sugarcane bagasse and detoxification of hemicellulosic hydrolysate}

$\mathrm{OA}$ is a strong organic acid, and due to its di-carboxylic properties, is better for hemicellulose hydrolysis than mineral acids such as sulfuric or hydrochloric acid [13]. OAFEX pretreatment is known for its precise action to degrade hemicellulose with fewer inhibitors and increased surface area of cellulose for improved enzymatic action [11,13,14,22,23]. The dilute OA hydrolysis of $\mathrm{SB}\left(160^{\circ} \mathrm{C} ; 3.5 \% \mathrm{OA} \mathrm{w} / \mathrm{v} ; 10 \%\right.$ total solids; $20 \mathrm{~min}$ residence time) depolymerized the hemicellulose fraction of the bagasse cell wall into sugars (xylose $12.56 \mathrm{~g} / \mathrm{l}$, glucose $1.85 \mathrm{~g} / \mathrm{l}$, arabinose $0.85 \mathrm{~g} / \mathrm{l}$ ) with the hemicellulose conversion (90.45\%) and inhibitors $(0.234 \mathrm{~g} / \mathrm{l}$ furfurals, $0.103 \mathrm{~g} / \mathrm{l}$ 5-hydroxy methyl furfural (5-HMF), $1.47 \mathrm{~g} / \mathrm{l}$ acetic acid and $2.95 \mathrm{~g} / \mathrm{l}$ total phenolics) (Table 1). Diluted OA hydrolysis degrades the hemicellulosic fraction of the plant cell wall into its monomeric constituents, such as xylose and other sugars, in addition to inhibitory compounds [13,22].

After hemicellulose is removed from the substrate during the OAFEX treatment, the leftover solid material, called cellulignin, becomes accessible for enzymatic saccharification. Critical factors such as lignocellulosic substrate, temperature, acid load, residence time, and substrateto-liquid ratio play key roles in breaking down hemicellulose into its monomeric constituents $[13,14]$, in addition to releasing inhibitors from the substrate [17]. Scordia et al. [12] reported $30.70 \mathrm{~g} / \mathrm{L}$ xylose (93.73\% conversion), 2.60 $\mathrm{g} / \mathrm{L}$ glucose (54.17\% conversion), $1.40 \mathrm{~g} / \mathrm{L}$ arabinose, 3.60 $\mathrm{g} / \mathrm{L}$ acetic acid, $0.68 \mathrm{~g} / \mathrm{L}$ furfurals, $0.10 \mathrm{~g} / \mathrm{L} \mathrm{HMF}$, and 6.58 $\mathrm{g} / \mathrm{L}$ phenolics from $S$. spontaneum under the hydrolytic conditions $\left(158^{\circ} \mathrm{C}, 16 \mathrm{~min}, 3.21 \% \mathrm{w} / \mathrm{w} \mathrm{OA}\right.$, solid-to-liquid ratio of 1:4). The OA-mediated hydrolysis of giant reed (Arundo donax L.) revealed $100 \%$ recovery of xylose, arabinose, glucose, $6.55 \mathrm{~g} / \mathrm{L}$ furfural, and $0.18 \mathrm{~g} / \mathrm{L} \mathrm{HMF}$ at defined hydrolysis conditions, i.e. $190^{\circ} \mathrm{C}, 25 \mathrm{~min}, 5 \%$ w/w OA [11]. Maize residues pretreated with OA $\left(160^{\circ}\right.$ C, $1.8 \%$ OA, 10 min residential time) showed $28 \pm 2.5 \%$ w/w xylose yield [23]. These studies reveal the potential of OA pretreatment for hemicellulose degradation into fermentable sugars. 
Table 1 Sugarcane bagasse hemicellulosic hydrolysate profile after detoxification by calcium hydroxide overliming

\begin{tabular}{lccc}
\hline Constituents & Quantity $(\mathbf{g} / \mathbf{l})$ & \% Reduction after overliming & Residual constituents quantity (g/l) \\
\hline Xylose & 12.56 & 7.51 & 11.61 \\
Glucose & 1.85 & 25.50 & 1.37 \\
Arabinose & 0.85 & 8.56 & 0.777 \\
Acetic acid & 1.47 & 5.54 & 1.38 \\
Furfural & 0.242 & 23.96 & 0.184 \\
5-HMF & 0.094 & 10.63 & 0.084 \\
Total phenolics & 2.95 & 45.5 & 1.60 \\
\hline
\end{tabular}

The values are mean of three replicates. Standard deviation was within $10 \%$.

Fermentative inhibitors are common in acidic hydrolysis of SB. OA hydrolysate can be detoxified effectively using calcium hydroxide overliming: raising the $\mathrm{pH}$ of hydrolysate to 10.0. Regardless the source of availability of lignocellulosic hydrolysate, the detoxification using calcium hydroxide overliming is tedious and a subject of further investigation. It is an intensive step which cause precipitation and stirring problems. The re-adjustment to $\mathrm{pH} 6.0$ showed efficient removal of inhibitors from the hydrolysate (Table 1). After $\mathrm{Ca}(\mathrm{OH})_{2}$ overliming of the SB hemicellulosic hydrolysate, a significant reduction in furfurals (23.96\%), 5-HMF (10.63\%), total phenolics (45.5\%), and acetic acid (5.54\%) was observed with a marginal loss in xylose (7.51\%), glucose (25.50\%), and arabinose (8.56\%) (Table 1). During $\mathrm{Ca}(\mathrm{OH})_{2}$ overliming at $\mathrm{pH} 10$, precipitation of furfurals and phenolics occurs, resulting in their removal during vacuum filtration of the hydrolysate. Earlier, we have reported $41.75 \%$ and $33.21 \%$ reductions in furans and phenolics from $S$. spontaneum hemicellulosic hydrolysates after $\mathrm{Ca}(\mathrm{OH})_{2}$ overliming [24]. There was only a 5.5\% reduction in acetic acid content after overliming. In another study, Rodrigues et al. [22] observed no change in acetic acid concentration after overliming of corn stover hemicellulosic hydrolysate.

\section{Enzymatic hydrolysis}

OAFEX-treated bagasse was enzymatically hydrolyzed with commercial enzymes, i.e., $20 \mathrm{FPU} / \mathrm{g}$ of Celluclast $1.5 \mathrm{~L}$ and $30 \mathrm{IU} / \mathrm{g}$ of Novozym 188 at $50^{\circ} \mathrm{C}$ for $96 \mathrm{~h}$ in the presence of tween-20. Enzymatic hydrolysis after $72 \mathrm{~h}$ revealed $28.5 \mathrm{~g} / \mathrm{L}$ glucose release with $66.51 \%$ saccharification efficiency (Figure 1). The OAFEX-treated bagasse showed a concomitant increase in sugar recovery up to $72 \mathrm{~h}$ followed by a decrease in glucose concentration at $96 \mathrm{~h}$ of incubation. These enzyme loadings in the presence of surfactants are sufficient to hydrolyse the cellulose present in pretreated substrate.

A similar trend was reported in the sugar recovery during enzymatic hydrolysis of aqueous-ammonia-pretreated $S$. spontaneum [25]. The amounts of enzymes required for hydrolysis of pretreated raw material depend upon the pretreatment applied to the substrate and the availability of carbohydrate content in the substrate [26]. A maximum yield of sugars $(482 \pm 22 \mathrm{mg} / \mathrm{g}, 64 \%$ hydrolytic efficiency) from acidic-hydrolyzed wheat straw $(7.83 \%$ DS, acid loading $0.75 \%$ ) was obtained after enzymatic hydrolysis [26]. We also observed $28.5 \mathrm{~g} / \mathrm{l}$ glucose representing $66.51 \%$ efficiency after enzymatic hydrolysis of OAFEX-treated bagasse in the presence of tween-20 (2.5 g/l). Zheng et al. [27] observed that high enzyme loadings did not alter saccharification and yields. Rezende et al. [8] reported 72\% cellulose conversion from consecutive acid-base pretreated SB. A $65 \%$ cellulose conversion was obtained after the enzymatic hydrolysis $(1.91 \% \mathrm{w} / \mathrm{w}$ pretreated SB, $20 \mathrm{FPU} / \mathrm{g}$ enzyme loading, $0.05 \mathrm{~g} / \mathrm{g}$ surfactant) of bagasse pretreated with dilute sulfuric acid $(1.75 \% \mathrm{w} / \mathrm{w}$ bagasse content, $1.7 \% \mathrm{w} / \mathrm{w} \mathrm{H}_{2} \mathrm{SO}_{4}$ loading, $150^{\circ} \mathrm{C}$, and 30 min pretreatment time) [20]. Our results indicate that hemicellulose removal and the possible relocalization of lignin moieties during OAFEX treatment could yield the desired amount of sugar toward the goal of developing an intensified and simplified process for cellulose saccharification.

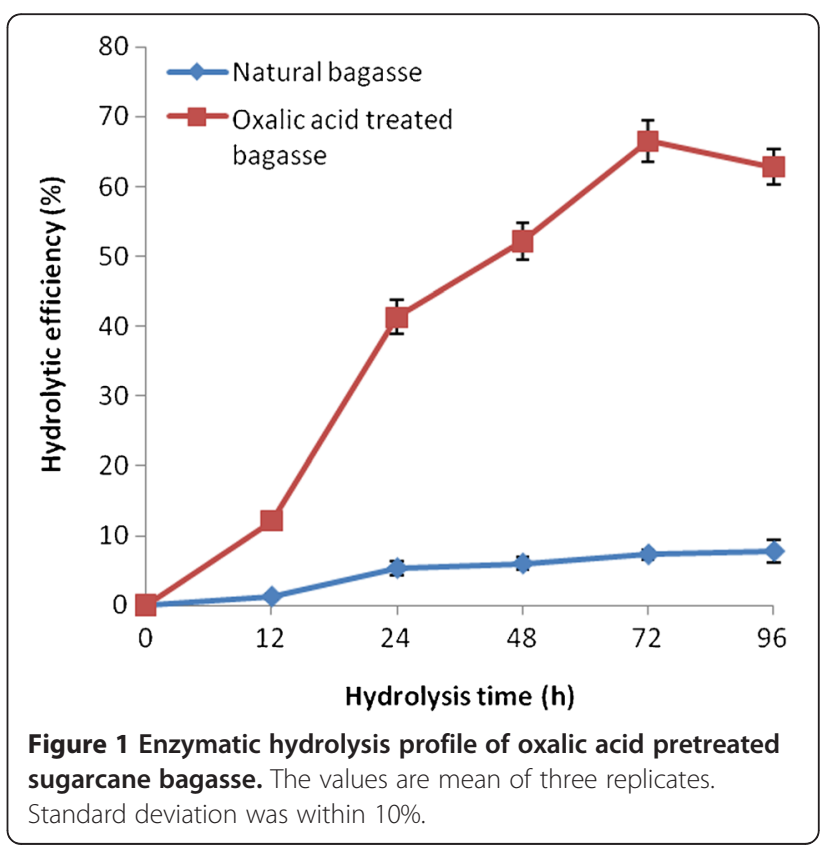


Ultra structural characterization of native and treated SB $\mathrm{SB}$, the biomass is naturally built through a special arrangement of cross-linked lignin with a holocellulose network, providing a superb mechanism to protect itself from microbial invasions in nature [5]. Rendering the carbohydrate fraction of the cell wall accessible is a multiscale phenomenon encompassing several orders of magnitude due to both macroscopic (compositional heterogeneity, mass transfer limitations) and microscopic barriers (holocellulose crystallinity, lignin-cellulose linkage) [28]. The pretreatment allows cellular breakdown, increasing the amenability of enzymes for sugar monomer recovery. The SEM and AFM of cell walls after acidic treatment reveal disorganization of cell wall components, which is pivotal for improved cellulase action on the carbohydrate polymer in order to yield simple sugars.

\section{Cell wall composition}

A physico-chemical analysis of the native SB cell wall revealed a composition (dry weight) of $24.67 \%$ total lignin (20.88\% Klason lignin $+3.79 \%$ acid soluble lignin), $41.22 \%$ cellulose, 25.62\% hemicellulose, 2.90\% extractives, $8.16 \%$ moisture, and $1.5 \%$ structural ash. This composition of SB is in agreement with earlier studies [20]. The treated substrate after OA pretreatment of SB revealed $58.84 \%$ cellulose, $8.75 \%$ hemicellulose, and $24.56 \%$ total lignin (24.18\% Klason lignin $+0.38 \%$ acid soluble lignin). The total lignin content in natural and OA-pretreated bagasse was determined to be almost similar (OA: 24.56\%; natural: $24.67 \%)$. Klason lignin content increased in the OA-treated bagasse (24.18\%) compared to the native bagasse (20.88\%). However, acid-soluble lignin was removed maximally in the OA-pretreated bagasse, making the total content almost similar.

The pretreatment of corn cob with OA showed 100\% removal of hemicellulose with a partial increase in lignin. Lee et al. [13] observed $6.76 \%$ xylan, $35.09 \%$ glucan, $0.12 \%$ galactan, $0.55 \%$ arabinan, and $12.09 \%$ lignin in OApretreated corn $\operatorname{cob}\left(168^{\circ} \mathrm{C}, 26 \mathrm{~min}, 30 \mathrm{~g} / \mathrm{l} \mathrm{OA}, 1: 6\right.$ solid-to-liquid ratio) compared with the native material (27.86\% xylan, $37.07 \%$ glucan, $0.61 \%$ galactan, $2.19 \%$ arabinan, and $13.92 \%$ lignin). The changes in cell wall composition of lignocellulosic material after OA pretreatment depend upon the nature of the substrate and the conditions explored during pretreatment [11-13].

\section{Scanning electron microscopy (SEM)}

SEM analysis indicated the cell wall degradation, and surface properties of native, OA-pretreated, and enzymatically digested SB (Figure 2a-c). The native SB cell wall showed parallel stripes and waxes, extractives, and other deposits on the surface (Figure 2a). Obtained results are in agreement with earlier studies, where OA was reported to disrupt the structure of fibers and pith by removing the hemicellulose fraction of the cell wall, waxes, and other deposits. OAFEX leaves the overall structure disorganized, simultaneously increasing the surface area for enzymatic action [14,23].

OA-pretreated bagasse fiber showed small pores on the surface and fiber disruption, which revealed the efficacy of the pretreatment process (Figure $2 \mathrm{~b}$ ). The OAFEX-treated SB revealed disruption of cell wall after enzymatic hydrolysis. Similarly, Rezende et al. [8] observed a disrupted fiber surface and exposed parallel stripes after sulfuric acid pretreatment of SB. Our data is in agreement and indicates severe disruption and exposure of parallel stripes in OAFEX-treated SB (Figure 2b). After the enzyme treatment of $\mathrm{SB}$, the analysis showed maximum disintegration and numerous holes in the cell wall, verifying the enzymatic action on cellulose (Figure 2c). The exposure of cellulose through structural alteration of the bagasse is the crucial factor in hydrolysis of the remaining cellulosic fraction present in the cell wall. Similar observations have been reported from enzymatic hydrolysis of dilute-sulfuric-acidpretreated S. spontaneum [24,25]. Kristensen et al. [29] also observed similar effect on wheat straw cell walls after hydrothermal pretreatment.

\section{Atomic force microscopy (AFM)}

Amplitude and phase images were captured to show the changes in secondary cell walls and thickened vascular bundle cell surfaces of native, OAFEX-treated, and enzymatically digested SB (Figure 3a-c). The native SB showed a fibrous network of cellulose, cross-linked lignin, and hemicellulose in the parenchyma of the primary wall (Figure 2a), which is also shown by the AFM image, intact with a uniform surface (Figure 3a). The native SB surface was predominantly hydrophobic $(95.40 \mathrm{~nm})$, as confirmed by the darker phase image (Figure 3a). OA specifically disrupts hemicellulose, retaining cellulose and lignin together. The OAFEX-treated SB clearly showed the non-homogeneous phase and globular surface deposition in the amplitude phase (Figure 3b). The AFM tip showed increased affinity toward hydrophilic regions $(192 \mathrm{~nm})$ that appear light in color due to a significant change in phase image (Figure $3 b$ ). The surface of OA-treated SB is non-uniform, encompassing irregularly shaped hydrophilic deposits, probably due to the exposure of cellulose. Chundawat et al. [28] observed similar patterns in corn stover after pretreatment with ammonium hydroxide.

The presence of globular and irregular shapes $(20-95 \mathrm{~nm}$ in diameter) can be characteristic of lignin deposits in the cell wall (Figure 3b). This interpretation is in accordance with the SEM analysis, where re-localization of lignin is apparent, linking with cellulose lamellae/ agglomerates (Figure 2b). Lignin re-localization is an important feature that may lead to enhanced enzymatic hydrolysis. OA markedly disrupts hemicellulose and simultaneously 


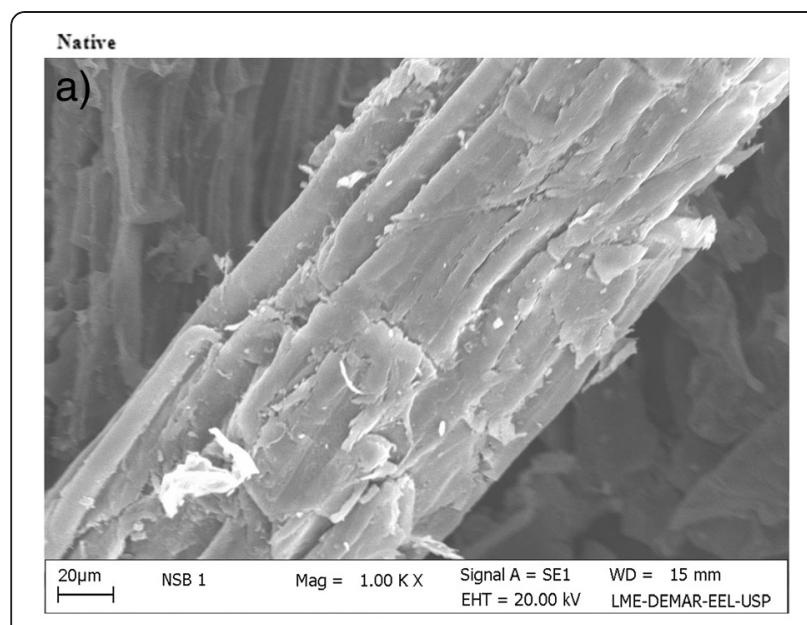

Oxalic acid pretreated

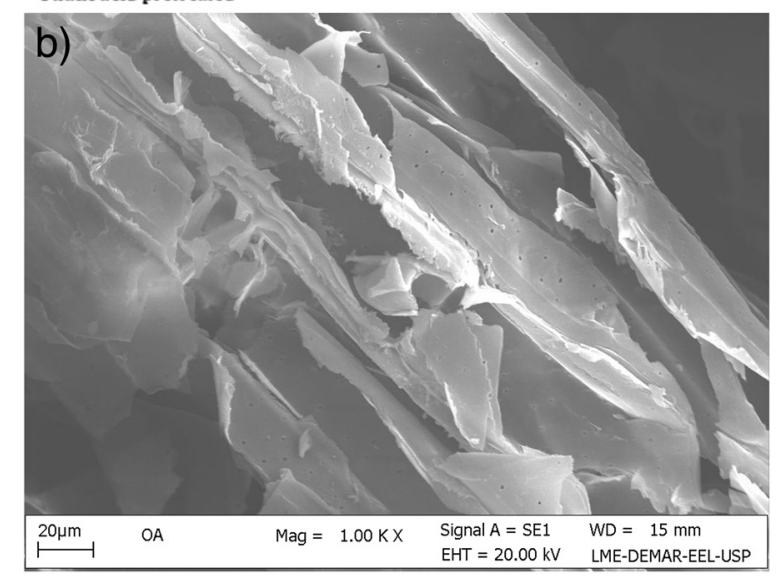

Enzymatic hydrolysed

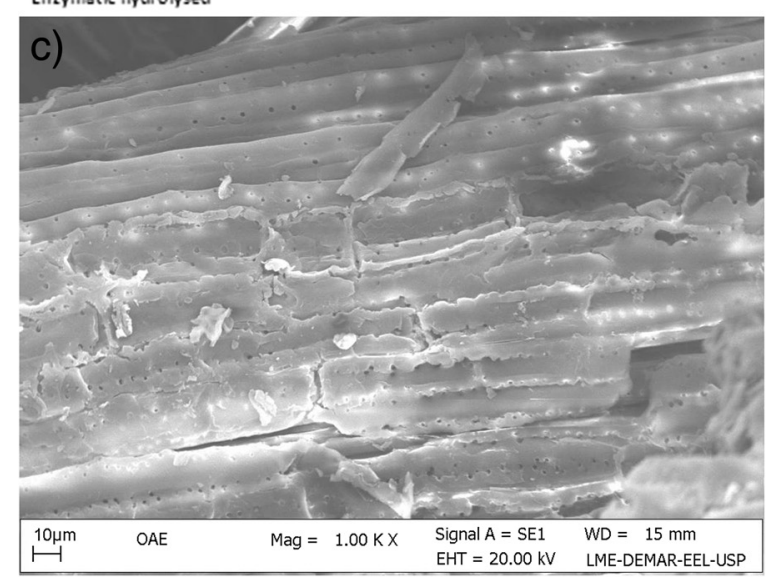

Figure 2 Scanning electron microscopy surface images of the sugarcane bagasse. (a) Native (b) Oxalic acid pretreated (c) Enzymatic hydrolysed. Compacted surface of cell wall showing waxes and deposits in native SB, disruption of cell wall was more evident after oxalic acid mediated pretreatment and enzymatic hydrolysis. re-localizes lignin moieties, aiding the increased exposure of cellulose to cellulases $[29,30]$.

The higher-resolution imaging of AFM reveals maximum non-uniformity in the cellulose lamellae, which can be interpreted as the complete disruption of cellulose aggregates into glucose (Figure 3c). The AFM tip showed high affinity toward hydrophilic areas (192 nm) appearing as changes in phase, and the light color shows the effective accessibility of cellulose to cellulases. Igarashi et al. [31] reported that the real-time visualization of cellulase from Trichoderma reesei cellobiohydrolase I action on crystalline cellulose resulted in marked cellulase affinity toward cellulose.

\section{X-ray diffraction (XRD)}

XRD analysis revealed the increasing order of crystallinity index (CrI) in OAFEX-treated bagasse (52.56\%) and enzyme-digested bagasse (55.65\%) compared to native bagasse (45.61\%). Figure 4 shows the XRD spectra of native, OAFEX-treated, and enzyme-digested bagasse. In general, after pretreatment of $\mathrm{SB}, \mathrm{CrI}$ increases with the decrease of amorphous regions in the substrate along with other constituents [6]. The CrI of OAFEX-treated bagasse increases mainly due to removal of hemicellulose in conjunction with re-localisation of lignin and partial disruption of cellulose. Rezende et al. [8] reported that the CrI of consequentially acid-base-pretreated SB increased with a parallel increase in the amount of cellulose in the substrate. Velmurugan and Muthukumar [7] observed a high CrI in sono-assisted alkali-pretreated SB (66\%) compared with natural bagasse $(50 \%)$. The increase in CrI of OAFEXtreated bagasse and enzyme-digested bagasse was due to the depolymerization of hemicellulose and cellulose into their monomeric constituents. Cellulase enzyme cocktails break down the amorphous cellulose, thus increasing the CrI over OAFEX-treated bagasse. However, cellulose crystallinity is not considered to be a principal factor that determines biomass recalcitrance [8].

\section{Raman spectroscopy}

Raman spectroscopic analysis revealed a gradual reduction in the band intensity $\left(<1500 \mathrm{~cm}^{-1}\right)$ in OAFEX-treated and enzymatically hydrolyzed $\mathrm{SB}$ compared to the native bagasse (Figure 5). The molecular disarrangement and displacement in the hemicellulosic backbone during pretreatment followed by enzymatic cleavage of the $\beta-1-4-$ glycosidic linkage of cellulose may have caused this gradual reduction in overall band intensities. Previous studies that performed Raman spectroscopic analysis of cellulose and hemicellulose showed that the changes in spectra were dominated by contributions from cellulose at intensities below $1500 \mathrm{~cm}^{-1}$ [32]. The ratio of the bands at $1172 \mathrm{~cm}^{-1}$ and $1204 \mathrm{~cm}^{-1}$ reflects the orientation of the cellulose relative to the electric vector (polarization) of the laser [33]. 

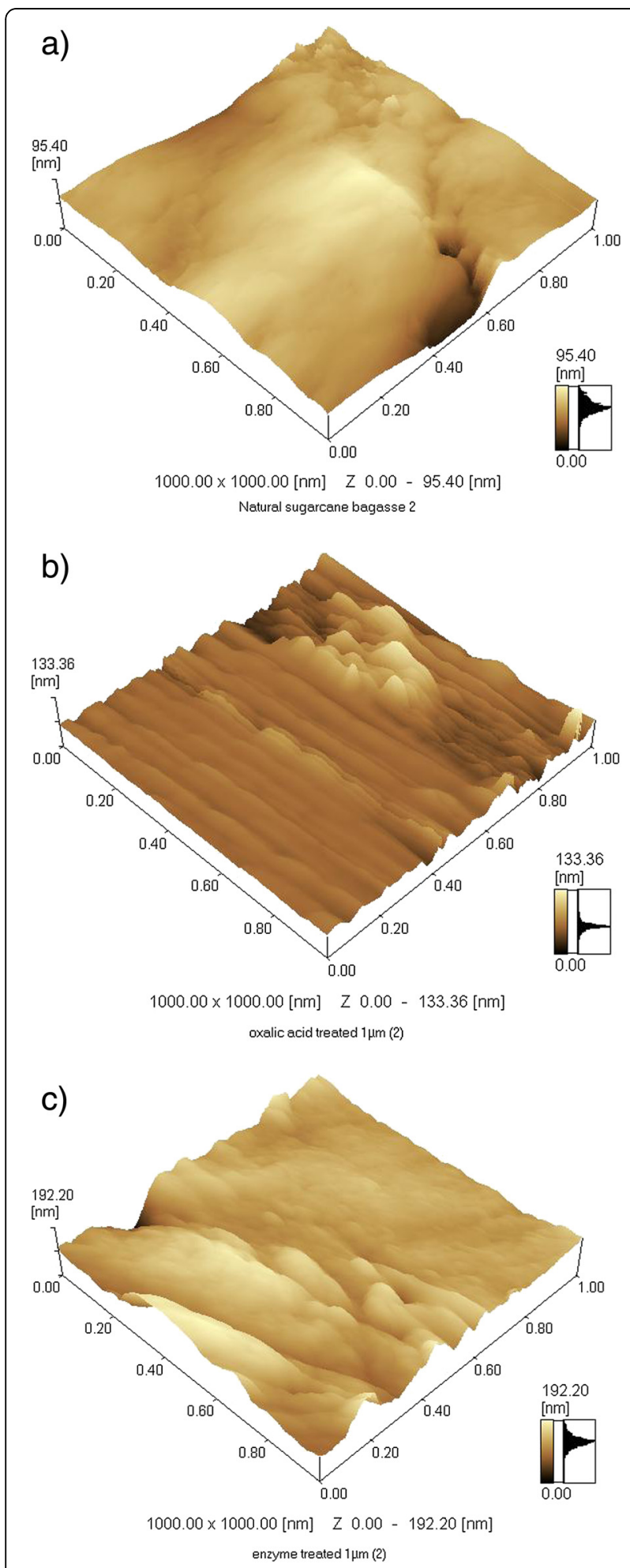

Figure 3 Atomic force microscopy (AFM) amplitude images. (a) Native sugarcane bagasse (b) Oxalic acid-pretreated bagasse (c) Enzyme hydrolysed bagasse. AFM scan revealed the cross linked cellulose + hemicellulose network in native SB. After OA pretreatment, non homogenous surface appeared with globular surface deposition (characteristic of lignin). AFM tip indicated affinity towards hydrophilic areas $(192 \mathrm{~nm})$ revealing the breakdown of cellulose.
In Raman analysis, the electric field vector has a component along the cellulose axis causing the intensification of the band at $1172 \mathrm{~cm}^{-1}$, and considered to obtain the spectral analysis of native, OAFEX-treated, and enzymedigested SB. Figure 5 shows cellulose/ hemicellulose peaks at 1088 and $1371 \mathrm{~cm}^{-1}$. It is evident here that OA pretreatment and enzymatic hydrolysis act on hemicellulose and cellulose respectively. In addition, the main signature of lignin in all three samples is strong band lines at 1603 and $1630 \mathrm{~cm}^{-1}$ due to stretching of the asymmetric aryl ring in lignin $[33,34]$. This may be due to the re-localization of lignin moieties during $\mathrm{OA}$ pretreatment of $\mathrm{SB}$ at a high temperature. Ooi et al. [34] reported that Raman spectra of native and $\mathrm{NaOH}$-treated Kenaf fibers showed a reduction in intensity of lignin bands in the region around $1750 \mathrm{~cm}^{-1}$ assigned to acetyl groups with the carbonyl, $\mathrm{C}=\mathrm{O}$ group. No significant changes were observed in the intensities of lignin bands at $1750 \mathrm{~cm}^{-1}$, maybe due to the fact that $\mathrm{OA}$ and enzymatic hydrolysis specifically act on hemicellulose and cellulose respectively.

\section{Fourier transform infrared spectroscopy (FTIR)}

FTIR spectroscopy was carried out to investigate the changes in hemicellulose and cellulose structure during OAFEX treatment and enzymatic hydrolysis. FTIR spectra of the native $\mathrm{SB}$ show a band at $900 \mathrm{~cm}^{-1}$ representing the $\beta-(1-4)$ glycosidic linkages of cellulose (Figure 6a-d). The frequency range between $1200-1000 \mathrm{~cm}^{-1}$ has a large contribution of hemicellulose and cellulose with maxima at $1037 \mathrm{~cm}^{-1}$ due to $\mathrm{C}-\mathrm{O}$ stretching mode and $1164 \mathrm{~cm}^{-1}$ due to the asymmetrical stretching C-O-C $[35,36]$. The absorption at $1247 \mathrm{~cm}^{-1}$ shows due to $\mathrm{C}-\mathrm{O}$ stretching and is a feature of the hemicelluloses, as well as of lignin [37]. There is divergence about the region at $1316 \mathrm{~cm}^{-1}$ (Figure 6b), which can be attributed to vibration of the $\mathrm{CH}_{2}$ group of cellulose [35]. Pandey attributes it to the $\mathrm{C}-\mathrm{O}$ syringyl ring in lignin [38].

The absorption around $1463 \mathrm{~cm}^{-1}$ refers to $\mathrm{CH}_{2}$ and $\mathrm{CH}_{3}$ deformation of lignin, while $1606 \mathrm{~cm}^{-1}$ is related to $\mathrm{C}=\mathrm{C}$ stretching of the aromatic ring (lignin) and $\mathrm{C}=\mathrm{O}$ stretching (Figure 6c). The absorption around $1515 \mathrm{~cm}^{-1}$ is associated with $\mathrm{C}=\mathrm{C}$ aromatic skeletal vibration [35,38]. The absorption in $1733 \mathrm{~cm}^{-1}$ is attributed to a $\mathrm{C}=\mathrm{O}$ unconjugated stretching of hemicelluloses but also with the contribution of lignin [35,38]. The small peaks at $2850 \mathrm{~cm}^{-1}$ and $2918 \mathrm{~cm}^{-1}$ come from $\mathrm{CH}_{2}$ and $\mathrm{CH}$ symmetric and asymmetric stretching respectively (Figure 6d). Both are characteristic of cellulose [36]. The obtained data agree that the range $3800-3000 \mathrm{~cm}^{-1}$ comprises bands related to the crystalline structure of cellulose [35]. The region is of great importance and is related to the sum of the valence vibrations of $\mathrm{H}$-bonded $\mathrm{OH}$ and intramolecular and intermolecular hydrogen bonds. In the range $1300-1000 \mathrm{~cm}^{-1}$, the appearance of 
two peaks at $1033 \mathrm{~cm}^{-1}$ and $1058 \mathrm{~cm}^{-1}$ were observed in OAFEX-treated bagasse and enzyme-digested cellulignin spectra respectively (Figure 6b). This indicates penetration of $\mathrm{OA}$ in the amorphous region of the biomass and degrading hemicellulose.

Further, the removal of the hemicelluloses is clearly seen by comparing the band around $1247 \mathrm{~cm}^{-1}$ with the abrupt decrease of the same band in the OAFEX-treated bagasse (Figure 6b). In the range $1800-1400 \mathrm{~cm}^{-1}$, we did not observe changes except around $1733 \mathrm{~cm}^{-1}$, which indicates chemical changes in hemicellulose and/or lignin (Figure 6c). Nevertheless, no apparent changes were observed in the lignin-characteristic bands around $1606 \mathrm{~cm}^{-1}, 1515 \mathrm{~cm}^{-1}$ and $1463 \mathrm{~cm}^{-1}$. Therefore, it is reasonable to state that the hemicellulose was degraded by the action of the OA, which appears to be less stable than lignin. These observations could reflect that the lignin composed of percentages of p-hydroxyphenyl $(\mathrm{H})$, guaiacyl (G), and syringyl (S) units is highly condensed and very resistant to degradation. Further, the $3000-2800 \mathrm{~cm}^{-1}$ range shows a decrease of two local maxima mainly in the enzyme-digested cellulignin, indicating the cellulose hydrolysis (Figure 6d).

FTIR spectroscopy, together with the deconvolution technique, provides distinct positions of the bands in this region. Gaussian distribution of the modes in the deconvolution process showed the three bands (Figure 7a-c). The band range from 3310 to $3228 \mathrm{~cm}^{-1}$ refers to the intermolecular hydrogen bond $\mathrm{O}(6) \mathrm{H} . . . \mathrm{O}(3)$ (Figure 7 ), 3375 to $3335 \mathrm{~cm}^{-1}$ belongs to the intramolecular hydrogen bond $\mathrm{O}$ (3) $\mathrm{H}$....O(5), and 3460 to $3410 \mathrm{~cm}^{-1}$ is related to the intramolecular hydrogen bond $\mathrm{O}(2) \mathrm{H}$.... $\mathrm{O}(6)$ (Figure 7). The band around $3585 \mathrm{~cm}^{-1}$ (band 1 in Figure 7) has been reported as the contribution of free hydroxyl [39].

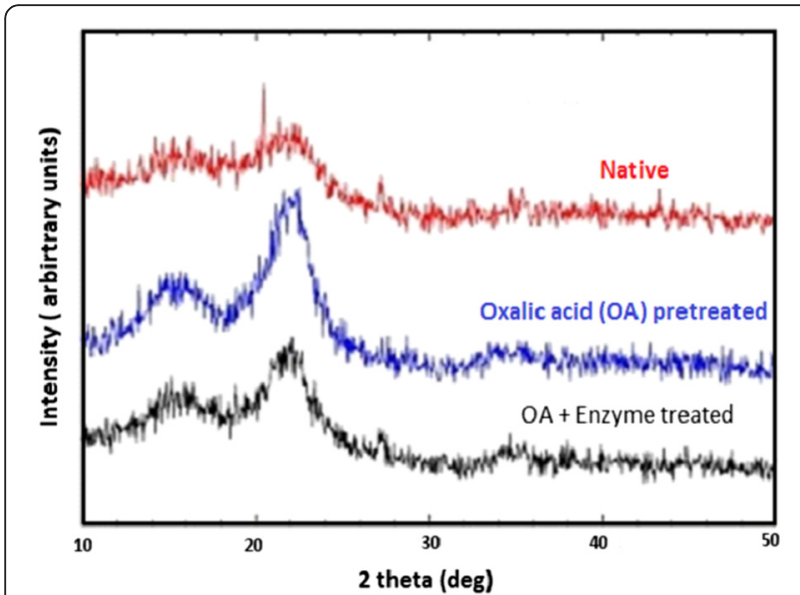

Figure 4 X-ray diffraction pattern of native, oxalic acid pretreated and enzyme hydrolysed SB. Crystallinity Index (Crl) was found to be increased in OA pretreated SB and enzymatic hydrolysed SB showing the effect of OAFEX and enzymatic degradation.
The deconvolution FTIR spectra reveal three bands of the crystalline structure of cellulose (Figure 7). Band 3 of intermolecular hydrogen bonds has shifted to a higher wave number $\left(3220 \mathrm{~cm}^{-1} ; 3239 \mathrm{~cm}^{-1} ; 3246 \mathrm{~cm}^{-1}\right)$, revealing the depolymerization of crystalline cellulose (Figure $7 \mathrm{~b}$ ). Band 2 of intramolecular hydrogen bonds has also shifted to higher frequencies $\left(3433 \mathrm{~cm}^{-1} ; 3443 \mathrm{~cm}^{-1} ; 3446 \mathrm{~cm}^{-1}\right.$ ) indicating the formation of intramolecular hydrogen bonds when OA penetrated the crystalline structure of cellulose (Figure 7c). This shift is evidence of an energy change in the internal interactions of cellulose $[40,41]$. The disruption of the structure of plant vegetal fibers and the removal of hemicellulose and/or lignin from the polymer matrix can also configure a closer relationship between the cellulose chains. Another indication of this behavior is the increase in the width and asymmetry of the curves for the OAFEX-treated bagasse.

\section{Near infrared spectroscopy (NIR)}

FT-NIR spectra of native, OAFEX-treated, and enzymedigested SB ranged from 7200 to $4000 \mathrm{~cm}^{-1}$ (Figure 8). The spectral region from 6000 to $5920 \mathrm{~cm}^{-1}$ is assigned to the first overtone $\mathrm{C}-\mathrm{H}$ stretching vibration of aromatics. This could be due to the re-localization of lignin moieties during OA-mediated pretreatment at a high temperature $[42,43]$. In regard to the hemicellulose structural change, the first overtone $\mathrm{C}-\mathrm{H}$ stretch around $5800 \mathrm{~cm}^{-1}$ is responsible for

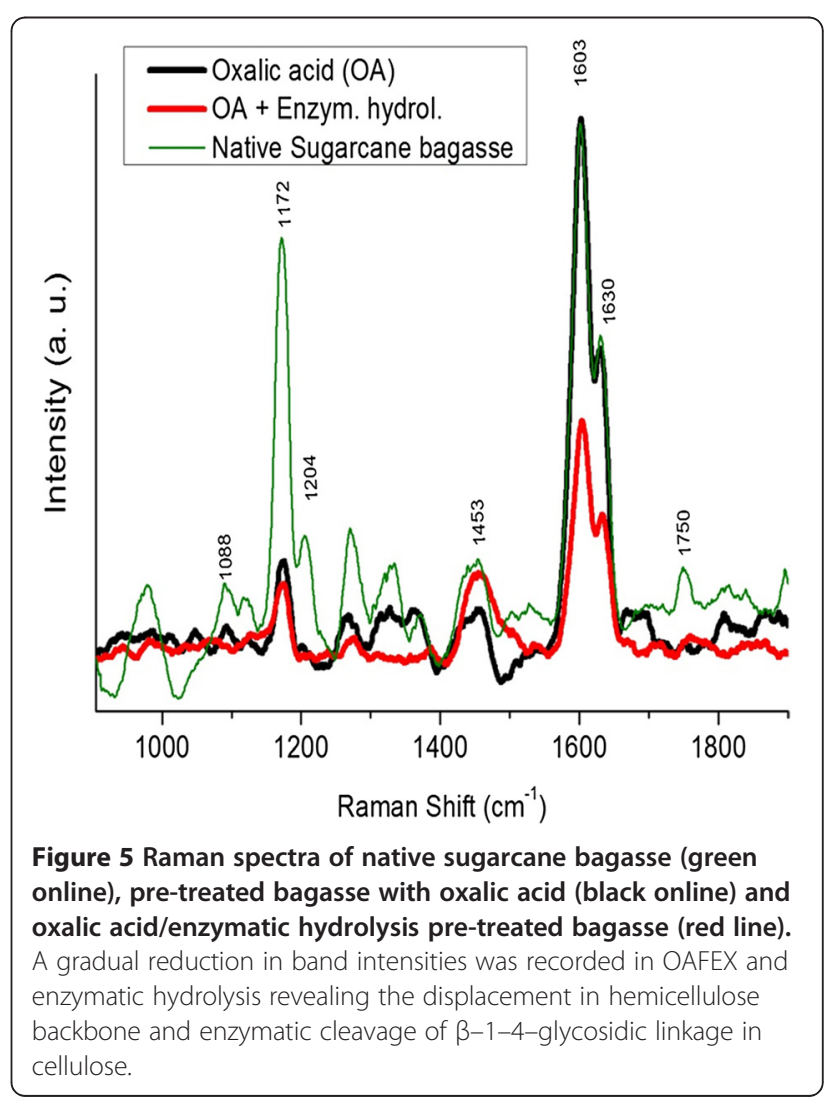


its variation $[42,44]$. This reveals that the absorbance of the hemicellulose decreases with diminishing hemicellulosic content in SB. This drastic change in absorbance in hemicellulose is due to the severe pretreatment given to the SB [42].

The stressed regions (grey) around $7000 \mathrm{~cm}^{-1}$ correspond to amorphous cellulose (Figure 8). The spectral band around $6290 \pm 20 \mathrm{~cm}^{-1}$ is attributed to crystalline cellulose (CII) and the presence of polysaccharides is shown at 5400 to $4000 \mathrm{~cm}^{-1}$ $[42,44]$. Additionally, we observed changes in the polysaccharide content in the regions around 6300, 5208, 4813, 4285, and $4405 \mathrm{~cm}^{-1}$. The amorphous region of polysaccharide around $7000 \mathrm{~cm}^{-1}$ had a small increase, suggesting the re-localization of lignin units [42].

\section{Ethanol fermentation}

Detoxified hemicellulosic hydrolysate and enzymatic hydrolysates were used for ethanol production using yeasts C. shehatae UFMG52.2 and S. cerevisiae 174 under submerged culture cultivation. The microorganisms selected for bioconversion of ethanol have been established for the fermentation of xylose and glucose sugars for ethanol production $[17,19]$.

\section{Fermentation of acid hydrolysate}

The fermentation profile of detoxified SB acid hydrolysate from C. shehatae UFMG52.2 and S. cerevisiae 174 in batch culture is shown in Figure 9a, b. The microorganism $C$. shehatae reached maximum ethanol production $(3.20 \mathrm{~g} / \mathrm{l})$ with a yield of $0.353 \mathrm{~g} / \mathrm{g}$ and productivity of $0.133 \mathrm{~g} / \mathrm{l} / \mathrm{h}$ from detoxified hemicellulosic acid hydrolysate after $24 \mathrm{~h}$, and declined afterwards (Figure 9a). The biomass continued to increase even after $24 \mathrm{~h}$ to the completion of the fermentation cycle $(72 \mathrm{~h})$, and yielded $0.385 \mathrm{~g} / \mathrm{g}$ with productivity of $0.0496 \mathrm{~g} / \mathrm{l} / \mathrm{h}$ (Table 2). The detoxified hemicellulose hydrolysate did not show satisfactory ethanol production (Figure $9 \mathrm{~b}$ ) by S. cerevisiae, which suggests that the microorganism was unable to utilize the abundance of xylose sugar in the hydrolysate. After $72 \mathrm{~h}$ of incubation, a

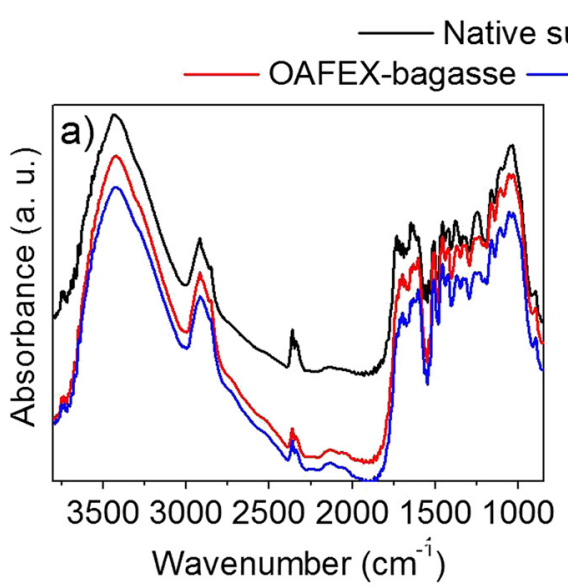

Enzyme digested cellulignin
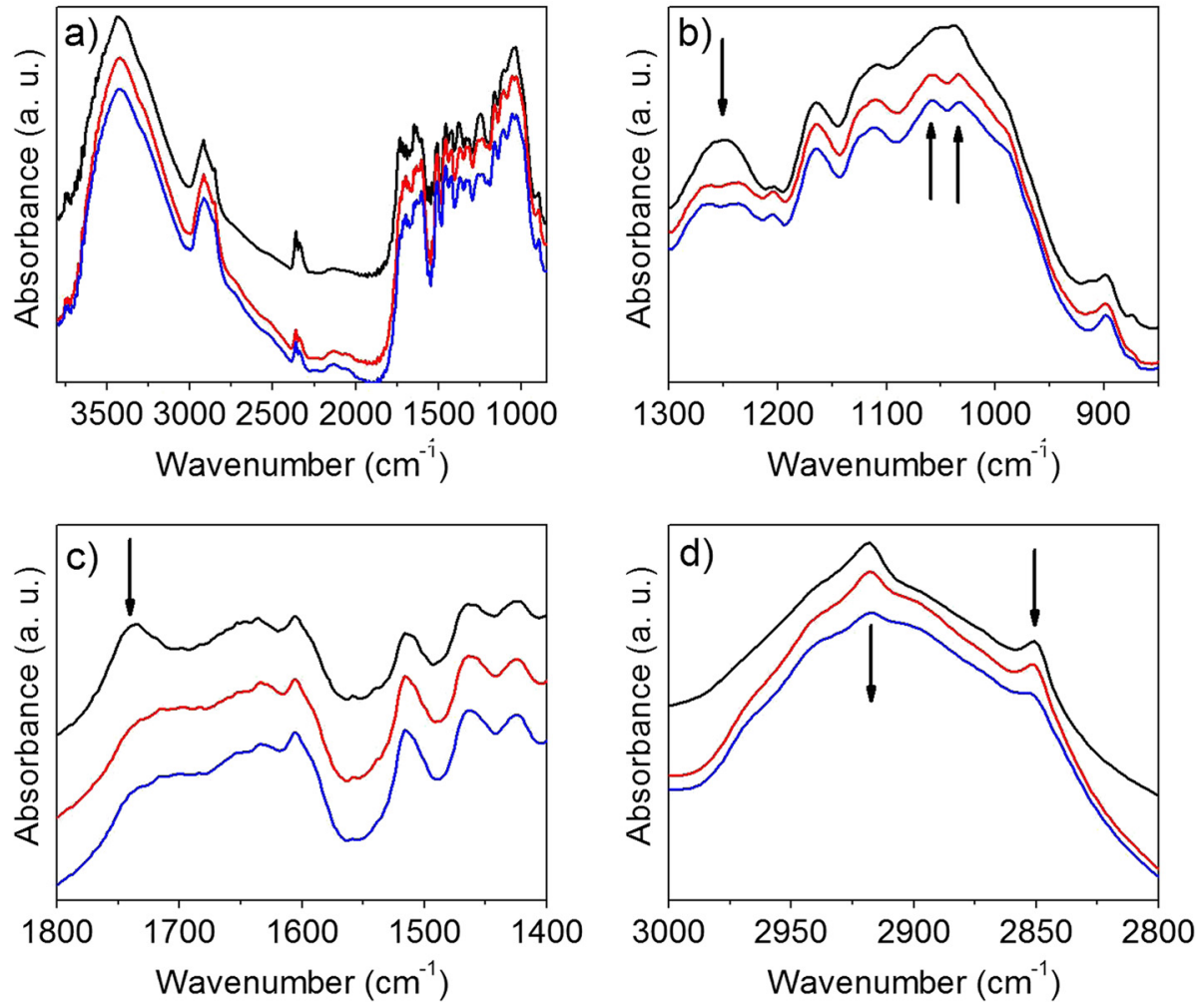

Figure 6 FTIR spectra of Native sugarcane bagasse (black online), Oxalic acid fiber expansion (OAFEX) (red online) and Enzyme digested cellulignin (blue online). 7b), 7c) and 7d) selected regions of Figure $\mathbf{7 a}$. The arrows indicate changes observed through the pretreatment. Hemicellulose and cellulose maxima appeared between frequency ranges of 1000-1200 $\mathrm{cm}^{-1}$ with maxima at $1037 \mathrm{~cm}^{-1}$ due to $\mathrm{C}-\mathrm{O}$ stretching. The absorption around $1463 \mathrm{~cm}^{-1}$ refers to $\mathrm{CH}_{2}$ and $\mathrm{CH}_{3}$ indicating the deformation of lignin while $1606 \mathrm{~cm}^{-1}$ is related to $\mathrm{C}=\mathrm{C}$ stretching of the aromatic ring (lignin) and $\mathrm{C}=\mathrm{O}$ stretching. 
biomass yield of $0.179 \mathrm{~g} / \mathrm{g}$ and productivity of $0.011 \mathrm{~g} / \mathrm{l} / \mathrm{h}$ were observed (Table 2).

\section{Fermentation of enzyme hydrolysate}

When the enzymatic hydrolysate was fermented with $C$. shehatae UFMG52.2, maximum ethanol production $(4.83 \mathrm{~g} / \mathrm{l})$ was found with a yield of $0.282 \mathrm{~g} / \mathrm{g}$ and productivity of $0.201 \mathrm{~g} / \mathrm{l} / \mathrm{h}$ after $24 \mathrm{~h}$ (Figure 10a; Table 2). However, regular growth of microorganisms was observed until the sugar was consumed after $72 \mathrm{~h}$. The maximum biomass production $(6.32 \mathrm{~g} / \mathrm{l})$ was obtained with a yield of $0.302 \mathrm{~g} / \mathrm{g}$ and productivity of $0.877 \mathrm{~g} / \mathrm{l} / \mathrm{h}$. Fermentation of enzymatic hydrolysate with $S$. cerevisiae showed maximum ethanol production $(6.6 \mathrm{~g} / \mathrm{l})$ after 24 $\mathrm{h}$, with a yield of $0.46 \mathrm{~g} / \mathrm{g}$ and productivity of $0.47 \mathrm{~g} / \mathrm{l} / \mathrm{h}$ after $14 \mathrm{~h}$ of incubation (Figure 10b). The growth in biomass remained unchanged until $72 \mathrm{~h}$ of incubation (Figure 10b; Table 2).

C. shehatae showed a greater ethanol yield $(0.353 \mathrm{~g} / \mathrm{g})$ from the acid hydrolysate than from the enzymatic hydrolysate $(0.282 \mathrm{~g} / \mathrm{g})$, indicating a microbial preference for xylose over glucose as a source of carbon in the fermentation reaction. However, $C$. shehatae is sensitive to fermentation inhibitors present in the hydrolysate. Sreenath et al. [45] showed ethanol production of $5 \mathrm{~g} / \mathrm{l}$ with a yield of $0.25 \mathrm{~g} / \mathrm{g}$ by $C$. shehatae FPL 702 from alfalfa hydrolysate. The low ethanol yield of this yeast was probably due to inhibition by pectic acid, organic acids, and hemicellulosederived inhibitors present in the sugar solution [45]. The hemicellulosic hydrolysates contain mainly xylose, while enzymatic hydrolysates contain only glucose. When $S$. cerevisiae was grown on hemicellulosic hydrolysate, abysmal ethanol production and growth were recorded (Table 2). S. cerevisiae does not use xylose present in the hemicellulosic hydrolysate, but rather relies upon glucose, which could be why the poor ethanol production was observed (Figure 9b). Our earlier studies showed that $S$. spontaneum acid hydrolysate after overliming fermented with $S$. cerevisiae $\mathrm{VS}_{3}$ in batch conditions produced $1.40 \pm 0.07 \mathrm{~g} / \mathrm{l}$ ethanol with $0.20 \pm 0.016 \mathrm{~g} / \mathrm{g}$ yield after $36 \mathrm{~h}$ of fermentation [24].

C. shehatae showed a similar growth pattern in both the hydrolysates. In both cases, more than $80 \%$ of the sugars were utilized within $24 \mathrm{~h}$ of incubation promoting faster growth of microorganism. Similar patterns of biomass growth were observed by Abbi et al. [46], and Chandel et al. [17] reported a regular increase in biomass of $C$. shehatae NCIM 3501 after the exhaustion of xylose in $24 \mathrm{~h}$ with the utilization of ethanol as a carbon source for the metabolic growth. Sánchez et al. [47] observed ethanol production $(4.5 \mathrm{~g} / \mathrm{L})$ from $C$. shehatae CBS4410 utilizing Paja brava acid hydrolysate $(19.8 \mathrm{~g} / \mathrm{L}$ xylose, $2.5 \mathrm{~g} / \mathrm{L}$ glucose) obtained under hydrolysis conditions $\left(180^{\circ} \mathrm{C}\right.$, $5 \mathrm{~min}, 0.5 \% \mathrm{w} / \mathrm{w} \mathrm{H}_{2} \mathrm{SO}_{4}$ ). Sreenath and Jeffries [48] reported that $C$. shehatae FPL-Y-049 utilized all sugars
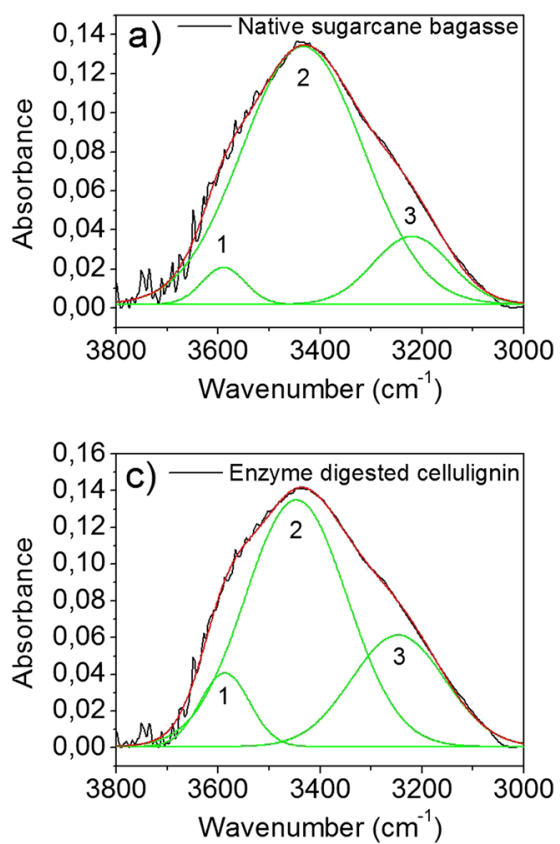

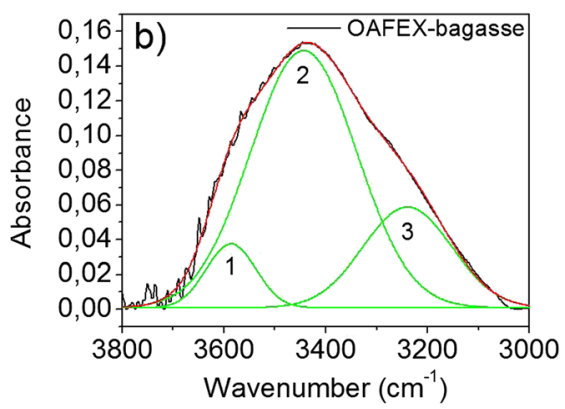

1: Free hydroxyl

2: Valence vibration of $\mathrm{H}$-bonded $\mathrm{OH}$ groups and intramolecular $\mathrm{H}$-bond $\mathrm{O}(2) \mathrm{H} \ldots \mathrm{O}(6)$

3: Intermolecular $\mathrm{H}$-bond $\mathrm{O}(6) \mathrm{H} . . . \mathrm{O}(3)$

$\begin{array}{lll}\text { Native SB } & \text { OAFEX SB } & \begin{array}{c}\text { Enzyme digested } \\ \text { cellulignin }\end{array} \\ \text { 1: } 3589 \mathrm{~cm}^{-1} & \text { 1: } 3585 \mathrm{~cm}^{-1} & 1: 3587 \mathrm{~cm}^{-1} \\ \text { 2: } 3433 \mathrm{~cm}^{-1} & 2: 3443 \mathrm{~cm}^{-1} & 2: 3446 \mathrm{~cm}^{-1} \\ \text { 3: } 3220 \mathrm{~cm}^{-1} & 3: 3239 \mathrm{~cm}^{-1} & 3: 3246 \mathrm{~cm}^{-1}\end{array}$

Figure 7 Deconvoluted FTIR spectra of a) Native sugarcane bagasse, b) Oxalic acid fiber expansion (OAFEX) and c) Enzyme digested cellulignin showing: the free hydroxyl (band 1), Valence vibration of $\mathrm{H}$-bonded $\mathrm{OH}$ groups and intramolecular $\mathrm{H}$-bond (band 2) and Intermolecular $\mathrm{H}$-bond (band 3 ). 
present in wood hemicellulose hydrolysate except arabinose and produced $34 \mathrm{~g} / \mathrm{L}$ of ethanol with a yield of $0.46 \mathrm{~g} / \mathrm{g}$.

The fermentation of enzymatic hydrolysate $(18.4 \mathrm{~g} / \mathrm{l}$ glucose) by $S$. cerevisiae produced maximum ethanol $(6.6 \mathrm{~g} / \mathrm{L}$, yield $0.46 \mathrm{~g} / \mathrm{g})$ after $14 \mathrm{~h}$ of incubation under conditions similar to those employed for hemicellulose hydrolysate fermentation (Figure 10b). It is interesting to note that both yeast strains isolated from Brazilian biodiversity presented a higher growth rate with a shorter lag phase and a prolonged exponential phase. The current growth pattern of both microorganisms supports maximal conversion of sugars into ethanol-an impressive trait for achieving higher ethanol productivity. These characteristics could be beneficial in biorefineries by saving time and reducing the cost of operation and energy.

The maximum ethanol productivity $(0.47 \mathrm{~g} / \mathrm{l} / \mathrm{h})$ was obtained from $S$. cerevisiae-mediated fermentation of OAFEX-treated SB enzymatic hydrolysate, another impressive feature of the $S$. cerevisiae strain used in this study (Table 2). Previously, a natural isolate from spent sulphite liquor, S. cerevisiae ATCC 96581, showed maximum ethanol production $(7.4 \mathrm{~g} / \mathrm{l}$, yield $0.28 \mathrm{~g} / \mathrm{g}$ and productivity $0.37 \mathrm{~g} / \mathrm{l} / \mathrm{h}$ ) from detoxified SB hydrolysate containing $26.0 \mathrm{~g} / \mathrm{l}$ total sugars [19]. Unlike acid hydrolysates, enzymatic hydrolysate lacks fermentative inhibitors, which eliminates the detoxification step. During the fermentation of enzymatic hydrolysate, $S$. cerevisiae showed less biomass production ( $4.03 \mathrm{~g} / \mathrm{l}$, yield $0.22 \mathrm{~g} / \mathrm{g}$ ) compared to C. shehatae (6.32 g/l, yield $0.302 \mathrm{~g} / \mathrm{g}$ ) after

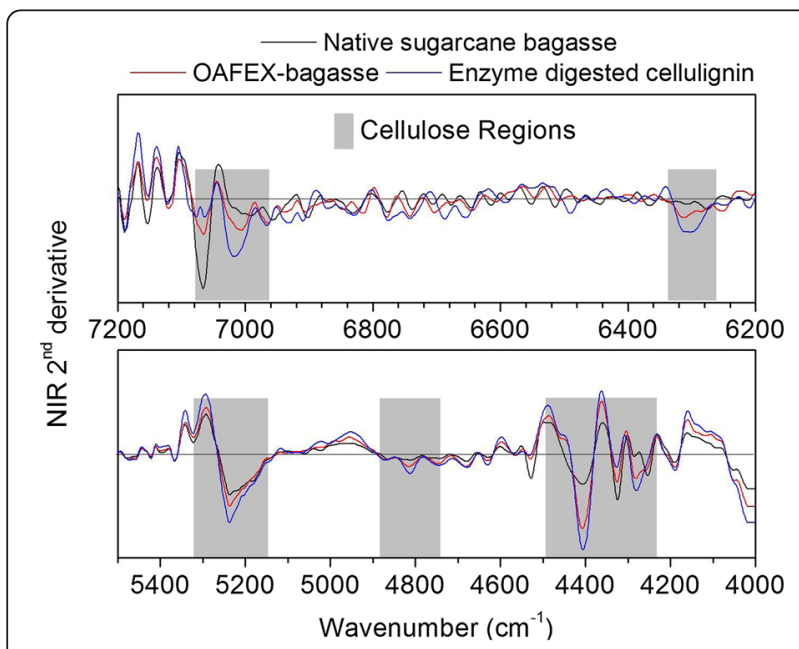

Figure 8 Second derivative of the NIR spectra (7200 to 4000 $\mathrm{cm}^{-1}$ ) of native sugarcane bagasse (black online), pre-treated bagasse with oxalic acid (red online) and enzymatic hydrolyzed bagasse (blue online). In the OAFEX-SB, spectral region 6000 to $5920 \mathrm{~cm}^{-1}$ is assigned to the $\mathrm{C}-\mathrm{H}$ stretching vibration of aromatics due to the re-localization of lignin. Changes in the polysaccharide content after OAFEX and enzyme hydrolysis at regions around 6300, $5208,4813,4285$, and $4405 \mathrm{~cm}^{-1}$
$72 \mathrm{~h}$ of incubation, suggesting that $C$. shehatae prefers to metabolize a carbon source for ethanol production rather than produce cellular buildup. However, the characteristic of selecting ethanol as a carbon source after the exhaustion of sugars was also observed in S. cerevisiae 174.

\section{Conclusion}

Plant cell walls are complex, rigid, and recalcitrant in nature. Pretreatment is an inevitable process to break down this carbohydrate skeleton and increase the accessibility of cellulose. Our studies indicated that OA-mediated hemicellulose degradation of SB is an effective pretreatment strategy that ameliorates the enzymatic hydrolysis of the cellulosic fraction into glucose. The microscopic and spectroscopic techniques used in this work warranted in-depth structural investigation of chemical changes at the molecular level during pretreatment and enzymatic digestion. OAFEX pretreatment significantly removed hemicellulose, causing lignin re-localization, which eventually showed efficient enzymatic action toward the depolymerization of cellulose into glucose (66.51\% hydrolytic efficiency). Detoxified hemicellulosic hydrolysate, when fermented by $C$. shehatae UFMG52.2 and S. cerevisiae 174, showed ethanol production of $3.20 \mathrm{~g} / \mathrm{L}$ (yield $0.353 \mathrm{~g} / \mathrm{g}$ ) and $0.52 \mathrm{~g} / \mathrm{L}$ (yield $0.246 \mathrm{~g} / \mathrm{g}$ ) respectively. Enzymatic hydrolysate after fermentation with C. shehatae UFMG52.2 and S. cerevisiae 174 produced $4.83 \mathrm{~g} / \mathrm{L}$ (yield $0.282 \mathrm{~g} / \mathrm{g}$ ) and $6.6 \mathrm{~g} / \mathrm{L}$ (yield $0.46 \mathrm{~g} / \mathrm{g}$ ) respectively. Both microorganisms revealed high substrate consumption including energy and time savings that could have a major impact in biorefineries.

\section{Material and methods}

\section{Preparation of raw substrate}

The raw substrate, sugarcane bagasse, was acquired from Usina Vale do Rosário (Morro Agudo, S.P, Brazil). In preliminary processing, the SB was air-dried, and knife milled (Marconi Equipamentos, Model No. MA 680, Piracicaba-S. $\mathrm{P}$, Brazil) to pass through with 20-mesh sieve. The finely milled bagasse was washed under running tap water to remove the dust, and dried at $45^{\circ} \mathrm{C}$ for further experiments.

\section{Oxalic acid fiber expansion pretreatment of sugarcane bagasse}

The pretreatment of the SB with dilute oxalic acid (OA) $\left(3.5 \% \mathrm{w} . \mathrm{v}^{-1}\right)$ was carried out at $160^{\circ} \mathrm{C}$ for $20 \mathrm{~min}$ as described by Scordia et al. [12]. Briefly, SB (10 g d.wt.)

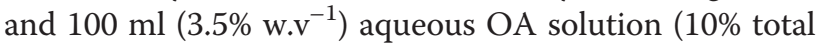
solids) were loaded into a $200 \mathrm{ml}$ stainless-steel container $(19 \times 9.7 \mathrm{~cm})$, tightly sealed and immersed in an oil bath provided with electrical heating at $160^{\circ} \mathrm{C}$. The container remains resident for $5 \mathrm{~min}$ to reach the temperature of $160^{\circ} \mathrm{C}$. The hydrolysis was stopped 


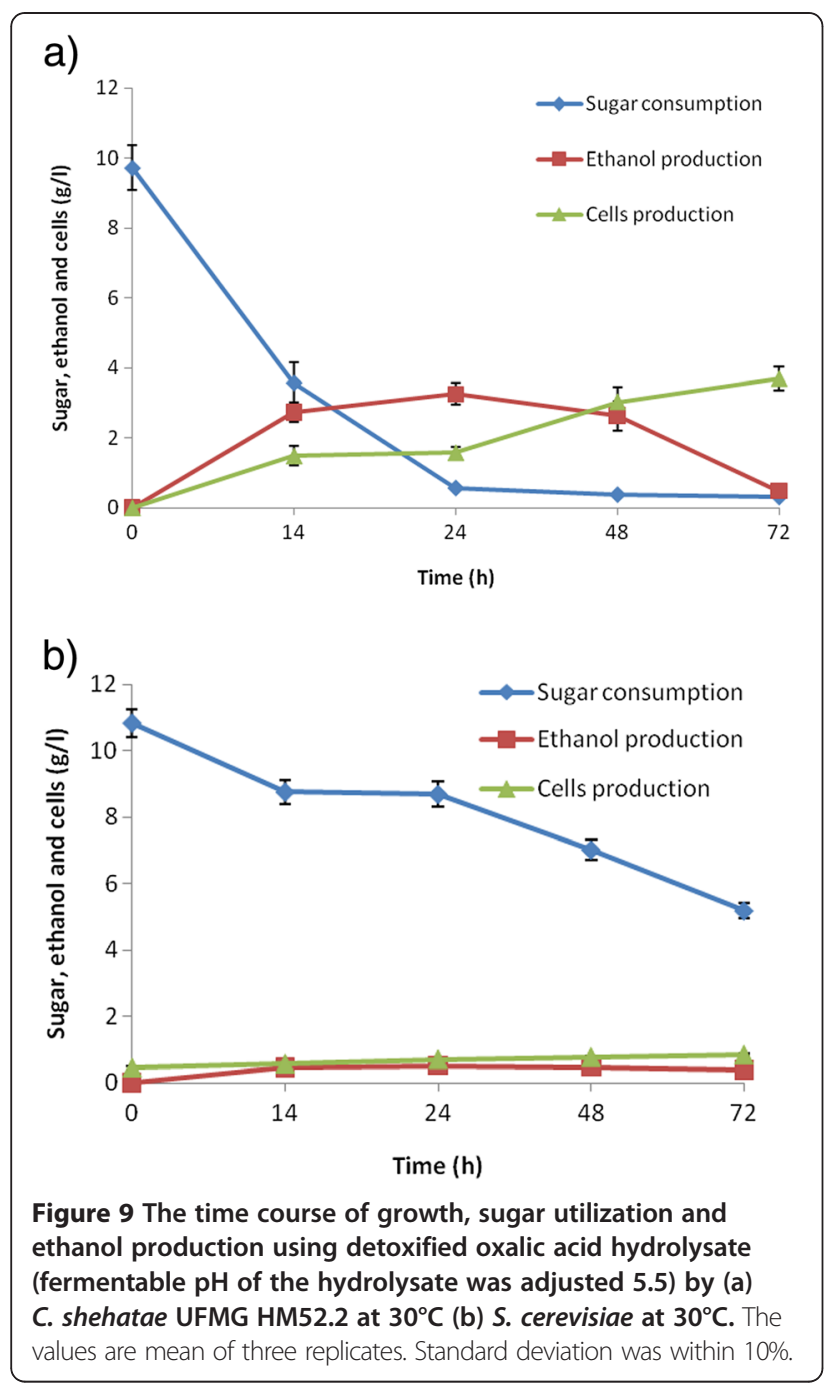

through immersing the container into running water in due course.

After hydrolysis, the hemicellulosic hydrolysate was quantitatively separated by vacuum filtration from the pretreated solids, hereinafter referred to as cellulignin. The cellulignin was thoroughly washed with deionized water and dried in oven at $45^{\circ} \mathrm{C}$ for $72 \mathrm{~h}$, and subsequently used for enzymatic hydrolysis.

\section{Detoxification of oxalic acid hydrolysate}

OA hydrolysate was detoxified using overliming with the addition of dried calcium oxide under constant stirring until the $\mathrm{pH}$ reached $10.5 \pm 0.05$. The fermentation inhibitors were allowed to precipitate for additional $1 \mathrm{~h}$ by stirring. The slurry was then subjected to vacuum filtration using Whatman filter paper \#1 to remove the precipitates. The $\mathrm{pH}$ of clear filtrate was adjusted to $6.00 \pm 0.05$ with $6 \mathrm{~N}$ $\mathrm{H}_{2} \mathrm{SO}_{4}$ and again vacuum filtered to remove traces of salt precipitates.

\section{Enzymatic hydrolysis}

OAFEX-bagasse was enzymatically hydrolysed to depolymerise carbohydrates into simpler sugars. The OAFEXbagasse ( $2 \mathrm{~g}$ d.wt) was pre-incubated in $40 \mathrm{ml}$ of sodium citrate buffer $(50 \mathrm{mM}, \mathrm{pH} 4.8)$ in $150 \mathrm{ml}$ Erlenmeyer flask for $1 \mathrm{~h}$ at room temperature. The microbial growth was restricted by adding sodium azide $(0.005 \%)$ during enzymatic hydrolysis. Soaked OAFEX-bagasse was supplemented with different cellulase loadings i.e. $20 \mathrm{FPU} / \mathrm{g}$ of the dry substrate from Celluclast $1.5 \mathrm{~L}$, and $30 \mathrm{IU} / \mathrm{g}$ of $\beta$-glucosidase from Novozym 188 (Sigma-Aldrich, USA). The reaction mixture was supplemented with non-ionic surfactant (2.5 g/l, Tween-20; polyoxyethylene sorbitan monolaurate). The enzymatic hydrolysis was performed at $50^{\circ} \mathrm{C}$ at $150 \mathrm{rpm}$ in incubator shaker (Innova 4000 Incubator Shaker, New Brunswick Scientific, Enfield, CT, USA) for 96 hrs. The samples $(0.5 \mathrm{ml})$ were collected periodically $(24 \mathrm{~h})$, centrifuged at 5000 rpm at room temperature. The supernatant was analyzed for total reducing sugars using DNS method [49]. The extent of hydrolysis (after OA pretreatment and enzymatic hydrolysis) was calculated as follows:

Hydrolysis (\%) $=$ reducing sugar concentration obtained $\times$ 100/Total carbohydrate content (TCC) in sugarcane bagasse.

\section{Fermentation}

\section{Microorganisms and inoculum preparation}

Microorganisms Candida shehatae UFMG HM 52.2 and Saccharomyces cerevisiae 174 were used for the fermentation of the hemicellulose hydrolysates and enzymatic hydrolysates. The microorganism C. shehatae UFMG HM 52.2 was isolated from a rotting-wood sample in an Atlantic Rain Forest site (Bello \& Kerida Ecological Reserve) situated in the city of Nova Friburgo, Rio de Janeiro state as described by Cadete et al. [50]. S. cerevisiae 174 was isolated from the Atibaia river, São Paulo State, Brazil. Both microorganisms were maintened on YPD plates and stored at $4^{\circ} \mathrm{C}$.

C. shehatae UFMG HM 52.2 was grown in $250 \mathrm{ml}$ Erlenmeyer flasks containing $50 \mathrm{ml}$ of seed medium (30 g/L of sugars (1:1 xylose and glucose), $20 \mathrm{~g} / \mathrm{l}$ peptone, and $10 \mathrm{~g} / \mathrm{l}$ yeast extract) in an orbital incubator shaker at $200 \mathrm{rpm}$ at $30^{\circ} \mathrm{C}$. Microorganism S. cerevisiae was grown in $250 \mathrm{ml}$ Erlenmeyer flasks containing $50 \mathrm{ml}$ of seed medium (30 g/l glucose, $5 \mathrm{~g} / \mathrm{l}$ peptone, $3 \mathrm{~g} / \mathrm{l}$ yeast extract, and $0.25 \mathrm{~g} / \mathrm{l}$ Di-ammonium hydrogen phosphate) in an orbital incubator shaker at $100 \mathrm{rpm}$ at $30^{\circ} \mathrm{C}$ for $24 \mathrm{~h}$. The cultured microorganisms (C. shehatae and S. cerevisiae) were centrifuged and prepared for inoculum corresponding to $0.5 \mathrm{~g} / \mathrm{l}$ cells (d. wt). The prepared inoculums were aseptically transferred into detoxified hemicellulosic and enzymatic hydrolysates $(50 \mathrm{ml})$ supplemented with medium ingredients. 


\section{Ethanol fermentation}

The fermentation medium $(50 \mathrm{ml})$ of microorganism C. shehatae UFMG HM 52.2 was composed of the hydrolysates (detoxified and enzymatic) supplemented with (g/l): yeast extract (3.0), malt extract (3.0), and ammonium sulfate (5.0) at $\mathrm{pH} 5.5$ [51]. In another set of fermentation, microorganism S. cerevisiae 174 was grown in the hydrolysates (detoxified and enzymatic) supplemented with (g/l): yeast extract (1.0), peptone (1.0), Di-ammonium hydrogen phosphate (1.0), Di-potassium hydrogen phosphate (1.0), magnesium sulfate and manganese sulfate $(0.5)$ at $\mathrm{pH} 5.5$ [24]. The hydrolysates were sterilized at $120{ }^{\circ} \mathrm{C}$ for $15 \mathrm{~min}$ before the use and the medium components were added aseptically prior to addition of inoculum. Fermentation reactions were setup in an orbital incubator shaker (Innova 4000 Incubator Shaker, New Brunswick Scientific, Enfield, CT, USA) at $200 \mathrm{rpm}$ (C. shehatae UFMG HM 52.2), and $100 \mathrm{rpm}$ (S. cerevisiae 174) for $72 \mathrm{~h}$. Samples $(1.0 \mathrm{ml})$ were collected periodically to determine the production of ethanol, residual sugars and formation of biomass in fermentation broth.

\section{Analyses}

The chemical composition pulverized sugarcane bagasse (native), OAFEX-SB, EH-SB was determined according to the method of Gouveia et al. [52]. Glucose, xylose, arabinose, and acetic acid, concentrations were determined by HPLC (Waters) using Biorad Aminex HPX-87H column at $45^{\circ} \mathrm{C}$ equipped with refraction index detector. The mobile phase was constituted with sulfuric acid $0.01 \mathrm{~N}$ at $0.6 \mathrm{~mL} / \mathrm{min}$ flow rate as eluent. Furfural and HMF concentrations were also determined by HPLC equipped with Hewlett-Packard RP18 column and UV-VIS detector (2489) $(276 \mathrm{~nm})$ at $25^{\circ} \mathrm{C}$. Samples were eluted by acetonitrile/water (1:8) supplemented with $1 \%$ acetic acid (volume basis) as the eluent at a flow rate of $0.8 \mathrm{ml} / \mathrm{min}$. Total phenolic compounds in hydrolysates were estimated calorimetrically using Folin-Ciocalteu method [53]. Ethanol production was analyzed by HPLC (Waters) using a refraction index detector (2414) and a Biorad Aminex HPX-87H column at $45^{\circ} \mathrm{C}$. The growth in biomass $C$. shehatae UFMG 52.2 and S. cerevisiae 174 was determined at $600 \mathrm{~nm}$ using spectrophotometer (Beckman DU640B, USA). The measured absorbance was correlated with the cell concentrations $(\mathrm{g} / \mathrm{l})$ following the calibration equation:

$$
\mathrm{Y}=2.0029 \mathrm{x}+0.0056 \text { (for C. shehatae UFMG 52.2) }
$$$$
\mathrm{Y}=1.0804 \mathrm{x}+0.006 \text { (for S. cerevisiae 174) }
$$

Pretreatment, enzymatic hydrolysis and fermentation experiments were carried out in triplicates. The values are mean of three replicates.

\section{Multi-scale visual analysis}

Scanning electron microscope (SEM)

The SEM analysis of native, OAFEX and enzymatically hydrolysed SB was performed as described by Kristensen et al. [29]. Briefly, native, OAFEX-pretreated and enzymatically hydrolysed SB distributed on a $12 \mathrm{~mm}$ glass cover slip coated with poly-L-lysine (Sigma Diagnostics, S.P. Brazil). The dried sections were mounted on aluminum stubs, sputter-coated (JEOL JFC-1600) with a gold layer, and used for scanning. The prepared samples were scanned and imaged using Hitachi S520 scanning electron microscope (Hitachi, Tokyo, Japan).

\section{Atomic force microscopy (AFM)}

The AFM analysis of native, OA pretreated and enzymatically hydrolysed SB was performed as described by Kristensen et al. [29]. All AFM measurements were

Table 2 Kinetic parameters for ethanol production from detoxified oxalic acid hydrolysate and enzymatic hydrolysates by Candida shehatae UFMG HM52.2 and Saccharomyces cerevisiae 174

\begin{tabular}{|c|c|c|c|c|}
\hline \multirow[t]{2}{*}{ Parameters } & \multicolumn{2}{|c|}{ Hemicellulose hydrolysate\# } & \multicolumn{2}{|c|}{ Enzyme hydrolysate\#\# } \\
\hline & C. shehatae & S. cerevisiae & C. shehatae & S. cerevisiae \\
\hline Initial sugars $\left(g_{s} /\right)$ & 9.61 & 10.25 & 21.03 & 18.4 \\
\hline Residual sugars $\left(\mathrm{g}_{\mathrm{s}} / \mathrm{l}\right)$ & 0.56 & 8.14 & 3.96 & 0.87 \\
\hline Ethanol $\left(g_{p} / l\right)$ & 3.20 & 0.52 & 4.83 & 6.6 \\
\hline Ethanol yield $\left(g_{p} / g_{s}\right)$ & 0.353 & 0.246 & 0.282 & 0.46 \\
\hline Ethanol productivity $\left(g_{p} / / / h\right)$ & 0.133 & 0.021 & 0.201 & 0.47 \\
\hline Biomass $\left(g_{x} / l\right)$ & 3.57 & 0.85 & 6.32 & 4.03 \\
\hline Biomass yield $\left(g_{x} / g_{s}\right)$ & 0.385 & 0.179 & 0.302 & 0.22 \\
\hline Biomass productivity $\left(g_{x} / / / h\right)$ & 0.0496 & 0.011 & 0.0877 & 0.055 \\
\hline
\end{tabular}

\#During the fermentation of hemicellulosic hydrolysate by C. shehatae UFMG HM52.2 and S. cerevisiae 174, maximum ethanol was produced after 24 hrs, so ethanol productivity was calculated in both the cases considering $24 \mathrm{hrs}$. After $24 \mathrm{hrs}$ of incubation, a concomitant downfall in ethanol production was observed with a regular increase in biomass. However, to calculate biomass productivities, incubation time (72 hrs) was considered.

\#\# During the fermentation of enzyme hydrolysate by C. shehatae UFMG HM52.2 and S. cerevisiae 174, maximum ethanol was produced after 24 hrs and 14 hrs respectively. Therefore ethanol productivities were calculated considering these incubation times. However biomass was found consistently increasing until the completion of fermentation ( $72 \mathrm{hrs}$ ), so biomass productivities were calculated considering $72 \mathrm{hrs}$ of incubation. The values are mean of three replicates. Standard deviation was within $10 \%$. 


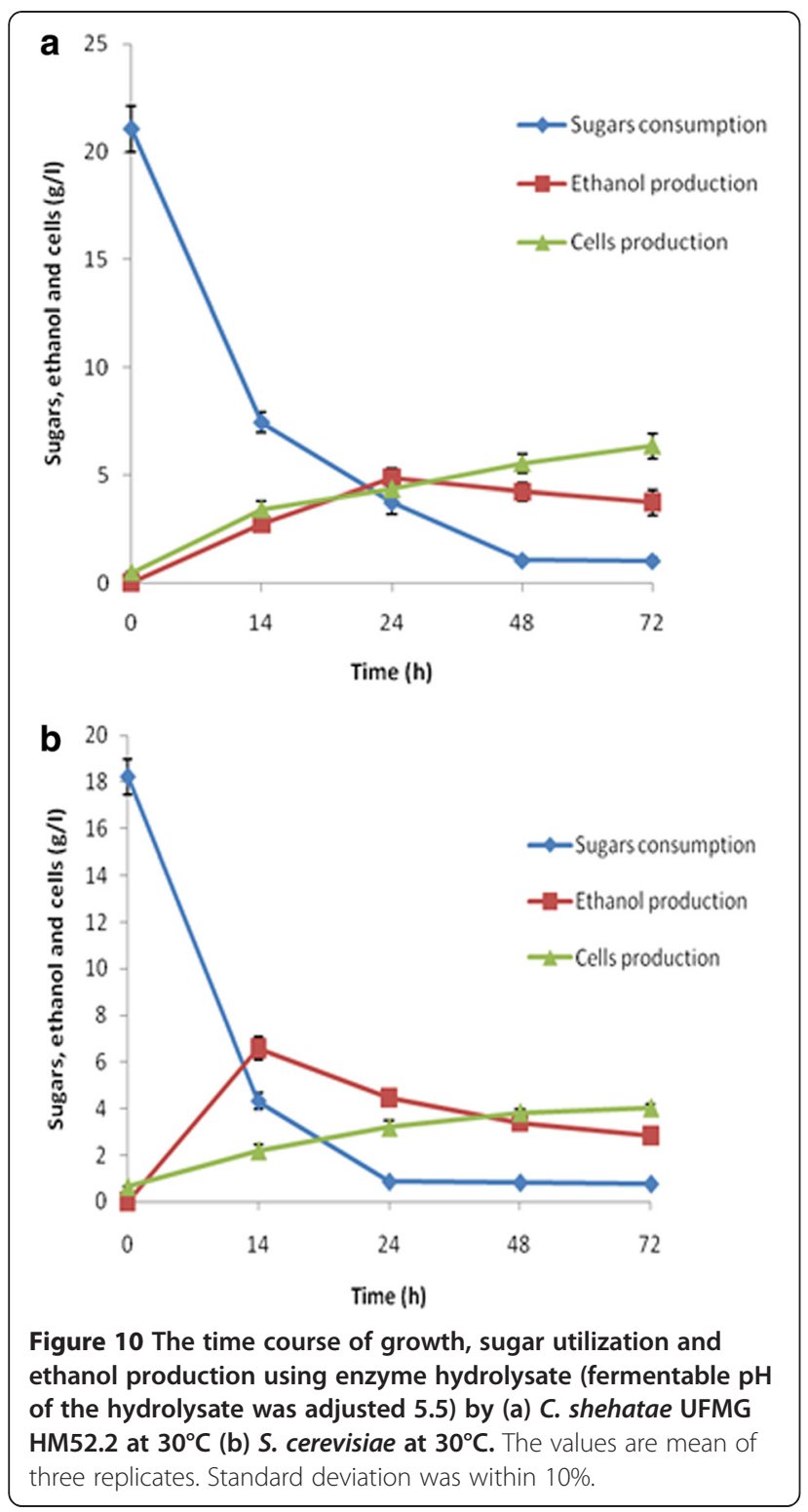

made with a multi-mode scanning probe microscope with a Nanoscope IIIa controller (Shimadzu SPM-9600 Deluxe, Japan). The images were acquired in tapping mode with etched silicon probe (Nanoworld Point Probe NCHR-10, $320 \mathrm{kHz}, 42 \mathrm{~N} / \mathrm{m}$ ). An auto-tuning resonance frequency range of approximately $286-305 \mathrm{kHz}$ with a scan rate of $0.5 \mathrm{~Hz}$ and sweep range of $10 \mathrm{kHz}$ was used. The drive amplitude and amplitude set-point were adjusted during measurements to minimize scanning artifacts. Height, amplitude and phase images were captured simultaneously. Scan size varied from $500 \mathrm{~nm}$ to $5.0 \mu \mathrm{m}$, usually $1 \mu \mathrm{m}$.

Samples were fixed on metal discs with double-sided adhesive tape, and the images were measured in air. Images were collected from a minimum of 10 different fibers for each treatment with representative images displayed in the present work. The external vibration noise was eliminated using active vibration-damping table. AFM images were recorded (512 dpi), analyzed and processed (illumination and plane fitting) by the accompanying software.

\section{X-ray diffraction (XRD)}

The crystalline nature of native, OA-treated and enzyme digested SB was analyzed by using a Scifert Isodebye Flex 3003 X-ray diffractometer (Germany). The crystallinity was analysed by adjusting the diffractometer set at $40 \mathrm{KV}, 30 \mathrm{~mA}$; radiation was $\mathrm{Cu} \mathrm{K \alpha}(\lambda=1.54 \AA)$. Samples were scanned over the range of $100<2 \theta<500$ with a step size of $0.05^{\circ}$ and the crystallinity index (CrI) were determined using the empirical method described by Segal et al. [54]:

$$
C r I=\frac{I \text { crytalline }-I \text { amorphous }}{I \text { crystalline }} \quad X 100 \%
$$

Where, I crystalline $=$ intensity at $21^{\circ} \mathrm{C}$ and $\mathrm{I}$ amorphous $=$ intensity at $18.8^{\circ} \mathrm{C}$.

\section{Raman spectroscopy}

The Raman spectra of native, OA pretreated and enzyme digested SB were recorded via microRaman (T64000 Horiba Jobin Ivon, France) using the $488 \mathrm{~nm}$ line of an argon laser, $1800 \mathrm{~g} / \mathrm{mm}$ grating with a 50x objective. The samples were passed through the laser power of $\sim 2 \mathrm{~mW}$, and the scattered light were detected by a CCD system cooled with liquid nitrogen at the temperature of $-130^{\circ} \mathrm{C}$. To maximize the Raman signals, we have used the fact that the Raman intensity of the cellulose is dependent of the laser light polarization. Cellulose mediated polarization of laser light is dependent on the position of sample at the microscopic stage. The spectra are scaled to the cellulose peak at $1172 \mathrm{~cm}^{-1}$, baseline was subtracted and smoothed with adjacent-averaging with 30 points.

\section{Fourier transform infrared spectroscopy (FTIR)}

FTIR spectroscopic analysis was performed to detect the changes in functional groups after $\mathrm{OA}$ pretreated and enzyme digested SB in comparison to native SB. Samples were put to mill in agate cups for $1.5 \mathrm{hrs}$ with $400 \mathrm{rpm}$ $\left(\right.$ RETSCH $^{\circledR}$ PM 400) followed by passing through with an abronzinox sieve of 100 mesh size with an aperture of $150 \mu \mathrm{m}$. The pellets were prepared by mixing of 300 $\mathrm{mg}$ of spectroscopic grade $\mathrm{KBr}$ with $3 \mathrm{mg}$ of sample in an agate mortar. Each sample was then submitted to 10 tons for $3 \mathrm{~min}$ in a hydraulic press (SPECAC 25T, ATLASTM). The spectra were collected in a VERTEX 70 spectrometer (Bruker Optics, Germany) and submitted to $4 \mathrm{~cm}^{-1}$ of resolution and 72 scans per sample. 


\section{Fourier transform-Near infra-red spectroscopy (FT-NIR)} The FT-NIR spectroscopy of native, OA pretreated and enzyme digested SB samples was performed with a spectrometer FT-NIR MPA (multi-purpose analyser) from Bruker Optics, Germany. The measurements have used to diffuse reflectance which were analysed via an integrating macro sample sphere, the diameter of measured area was $15 \mathrm{~mm}, 32$ scans per sample were performed with a resolution of $4 \mathrm{~cm}^{-1}$ covering a range from 13000 to $3500 \mathrm{~cm}^{-1}$. Second derivative spectra were calculated with 21 smoothing points after unit vector normalization. All calculations were conducted with OPUS 6.5 version software.

\section{Competing interests}

The authors declare that they have no competing interests.

\section{Authors' contributions}

AKC planned and performed the biomass pretreatment, enzymatic hydrolysis, ethanol fermentation, as well as the analysis of the results and manuscript writing. AKC also coordinated the overall study. FAFA assisted in biomass characterization, fermentation experiments and helped the manuscript drafting. VA, MJVB and LNR jointly carried out the Raman Spectroscopy, FTIR and FT-NIR analysis and written related text in the manuscript. OVS analyzed all the results and reviewed the manuscript draft. CAR and FCP provided the yeast strains and fermentation methodology. Both analyzed the fermentation results and contributed to the drafting of the text related to fermentation. SSS coordinated the overall study, analysis of results and finalizing the manuscript. All authors suggested modifications to the draft and approved the final manuscript.

\section{Acknowledgements}

Authors are grateful to FAPESP (Process no 2008/57926-4 and 2010/11258-0) for the financial support and CNPq. FAFA gratefully acknowledges CAPES, CAR, VA, MJVB and LNR acknowledge to FAPEMIG, CNPQ and CAPES for the financial support. We are also thankful to Ms. Juliana RG Reis for her technical assistance. Authors also would like to thank Dr. Durval Rodrigues Jr., Dr. Paulo Suzuki from Engineering School of Lorena and Dr. Rogerio Hein, UNESP, Guaratingueta for SEM, XRD and AFM analysis respectively

\section{Author details}

'Department of Biotechnology, University of São Paulo, School of Engineering of Lorena, Estrada Municipal do Campinho- Caixa, Postal 116 12.602.810, Lorena/SP, Brazil. ${ }^{2}$ Material Spectroscopy Laboratory, Department of Physics, Federal University of Juiz de Fora, Juiz de Fora, MG 36036-330, Brazil. ${ }^{3}$ Division of Biological and Health Sciences, University of Pittsburgh Bradford, PA 16701, USA. ${ }^{4}$ Department of Microbiology, Federal University of Minas Gerais, Belo Horizonte, MG, Brazil. ${ }^{5}$ Department of Biochemistry and Microbiology, Institute of Biosciences CEIS/UNESP - Rio Claro/ SP, Brazil.

Received: 7 October 2012 Accepted: 8 January 2013

Published: 16 January 2013

\section{References}

1. Kerr RA: Energy supplies. Peak oil production may already be here. Science 2011, 331:1510-1511.

2. Goldemberg J: Ethanol for a sustainable energy future. Science 2007, 315:808-810.

3. Huber G, Dale BE: Grassoline at the Pump. Sci Amer July, 2009, 52-59.

4. Chandel AK, Silva SS, Carvalho W, Singh OV: Sugarcane bagasse and leaves: Foreseeable biomass of biofuel and bio-products. J Chem Technol Biotechnol 2012, 87:11-20.

5. Himmel ME, Ding SY, Johnson DK, Adney WS, Nimlos MR, Brady JW, Foust TD: Biomass recalcitrance: engineering plants and enzymes for biofuels production. Science 2007, 315:804-807.

6. Sindhu R, Binod P, Satyanagalakshmi K, Janu KU, Sajna KV, Kurien N, Sukumaran RK, Pandey A: Formic acid as a potential pretreatment agent for the conversion of sugarcane bagasse to bioethanol. Appl Biochem Biotechnol 2010, 162:2313-2323.

7. Velmurugan R, Muthukumar K: Utilization of sugarcane bagasse for bioethanol production: sono-assisted acid hydrolysis approach. Bioresour Technol 2011, 102:7119-7123

8. Rezende CA, de Lima MA, Maziero P, de Azevedo ER, Garcia W, Polikarpov I: Chemical and morphological characterization of sugarcane bagasse submitted to a delignification process for enhanced enzymatic digestibility. Biotechnol Biofuels 2011, 4:54.

9. Siqueira G, Milagres AMF, Carvalho W, Koch G, Ferraz A: Topochemical distribution of lignin and hydroxycinnamic acids in sugar-cane cell walls and its correlation with the enzymatic hydrolysis of polysaccharides. Biotechnol Biofuels 2011, 4:7.

10. Taylor CB, Talib MF, McCabe C, Bu L, Adney WS, Himmel ME, Crowley MF, Beckham GT: Computational investigation of glycosylation effects on a family 1 carbohydrate-binding module. J Biol Chem 2012, 287:3147-3155

11. Scordia D, Cosentino SL, Lee JW, Jeffries TW: Dilute oxalic acid pretreatment for biorefining giant reed (Arundo donax L.). Biomass Bioener 2011, 35:3018-3024.

12. Scordia D, Cosentino SL, Jeffries TW: Second generation bioethanol production from Saccharum spontaneum L. ssp. aegyptiacum (Willd.) Hack. Bioresour Technol 2010, 101:5358-5365.

13. Lee J-W, Houtman CJ, Kim H-Y, Choi I-Y, Jeffries TW: Scale-up study of oxalic acid pretreatment of agricultural lignocellulosic biomass for the production of bioethanol. Bioresour Technol 2011, 102:7451-7456.

14. Li X, Cai Z, Horn E, Winandy JE: Effect of oxalic acid pretreatment of wood chips on manufacturing medium-density fiberboard. Holzforschung 2011, 65:737-741

15. Jeffries TW: Engineering yeasts for xylose metabolism. Curr Opin Biotechnol 2006, 17:320-326.

16. Chandel AK, Singh OV, Chandrasekhar G, Rao LV, Narasu ML: Key-drivers influencing the commercialization of ethanol based biorefineries. J Comm Biotechnol 2010, 16:239-257.

17. Chandel AK, Kapoor RK, Singh AK, Kuhad RC: Detoxification of sugarcane bagasse hydrolysate improves ethanol production by Candida shehatae NCIM 3501. Bioresour Technol 2007, 98:1947-1950.

18. Li Y, Park JY, Shiroma R, Ike M, Tokuyasu K: Improved ethanol and reduced xylitol production from glucose and xylose mixtures by the mutant strain of Candida shehatae ATCC 22984. Appl Biochem Biotechnol 2012, 166:1781-1790.

19. Martín C, Galve M, Wahlbom F, Hagerdal BH, Jonsson LJ: Ethanol production from enzymatic hydrolysates of sugarcane bagasse using recombinant xylose-utilising Saccharomyces cerevisiae. Enzyme Microb Technol 2002, 31:274-282.

20. Santos VTO, Esteves PJ, Milagres AMF, Carvalho W: Characterization of commercial cellulases and their use in the saccharification of a sugarcane bagasse sample pretreated with dilute sulfuric acid. J Ind Microbiol Biotechnol 2011, 38:1089-1098.

21. Esteghlalian A, Hashimoto AG, Fenske JJ, Penner MH: Modeling and optimization of the dilute-sulfuric-acid pretreatment of corn stover, poplar and switch grass. Bioresour Technol 1997, 59:129-136.

22. Rodrigues RCLB, Kenealy WR, Jeffries TW: Xylitol production from DEO hydrolysate of corn stover by Pichia stipitis YS-30. J Ind Microbiol Biotechnol 2011, 38:1649-1655.

23. Mtui GYS: Oxalic acid pretreatment, fungal enzymatic saccharification and fermentation of maize residues to ethanol. Afr J Biotechnol 2011 11:843-851.

24. Chandel AK, Singh OV, Narasu ML, Rao LV: Bioconversion of Saccharum spontaneum (wild sugarcane) hemicellulosic hydrolysate into ethanol by mono and co-cultures of Pichia stipitis NCIM3498 and thermotolerant Saccharomyces cerevisiae VS $_{3}$. New Biotechnol 2011, 28:593-599.

25. Chandel AK, Singh OV, Chandrasekhar G, Rao LV, Narasu ML: Bioconversion of novel substrate, Saccharum spontaneum, a weedy material into ethanol by Pichia stipitis NCIM3498. Bioresour Technol 2011, 102:1709-1714.

26. Saha BC, Iten LB, Cotta MA, Wu YV: Dilute acid pretreatment, enzymatic saccharification and fermentation of wheat straw to ethanol. Proc Biochem 2005, 40:3693-3700.

27. Zheng Y, Pan Z, Zhang R, Wang D: Enzymatic saccharification of dilute acid pretreated saline crops for fermentable sugar production. Appl Ener 2009, 86:2459-2467. 
28. Chundawat SPS, Donohoe BS, Sousa LD, Elder T, Agarwal UP, Lu FC, Ralph J, Himmel ME, Balan V, Dale BE: Multi-scale visualization and characterization of lignocellulosic plant cell wall deconstruction during thermochemical pretreatment. Ener Environ Sci 2011, 4:973-984.

29. Kristensen JB, Thygesen LG, Felby C, Jørgensen H, Elder T: Cell-wall structural changes in wheat straw pretreated for bioethanol production. Biotechnol Biofuels 2008, 1/5:1-9.

30. Selig MJ, Viamajala S, Decker SR, Tucker MP, Himmel ME, Vinzant TB: Deposition of lignin droplets produced during dilute acid pretreatment of maize stems retards enzymatic hydrolysis of cellulose. Biotechnol Prog 2007, 23:1333-1339.

31. Igarashi K, Uchihashi T, Koivula A, Wada M, Kimura S, Okamoto T, Penttilä M, Ando T, Samejima M: Traffic jams reduce hydrolytic efficiency of cellulase on cellulose surface. Science 2011, 333:1279-1282.

32. Wiley $\mathrm{JH}$, Atalla RH: Band assignments in the Raman spectra of celluloses. Carbohyd Res 1987, 160:113-129.

33. Agarwal UP, Weinstock IA, Atalla RH: FT Raman spectroscopy for direct measurement of lignin concentrations in kraft pulps. Tappi J 2003, 2:22.

34. Ooi BG, Rambo AL, Hurtado MA: Overcoming the recalcitrance for the conversion of Kenaf pulp to glucose via microwave-assisted pretreatment processes. Int J Mol Sci 2011, 12:1451-1463.

35. Colom X, Carrillo F, Nogués F, Garriga P: Structural analysis of photodegraded wood by means of FTIR spectroscopy. Polym Degrad Stab 2003, 80:543-549.

36. Oh SY, Yoo D, Shin Y, Kim HC, Kim HY, Chung YS, Park WH, Youk JH: Crystalline structure analysis of cellulose treated with sodium hydroxide and carbon dioxide by means of X-ray diffraction and FTIR spectroscopy. Carbohyd Res 2005, 340:2376-2391.

37. Pandey KK, Pitman AJ: FTIR studies of the changes in wood chemistry following decay by brown-rot and white-rot fungi. Int Biodet Biodeg 2003 , 52:151-160.

38. Pandey KK: A study of chemical structure of soft and hardwood and wood polymers by FTIR spectroscopy. J Appl Polym Sci 1999, 12:1969-1975.

39. Kondo T: The assignment of IR absorption bands due to free hydroxyl groups in cellulose. Cellulose 1997, 4:281-292.

40. Cao Y, Huimin T: Structural characterization of cellulose with enzymatic treatment. J Mol Str 2004, 705:189-193.

41. Sun Y, Lin L, Deng HB, Li JZ, He BH, Sun RC: Structural changes in Bamboo cellulose in formic acid. BioRes 2008, 3:297-315.

42. Krongtaew C, Meesner K, Ters T, Fackler K: Qualitative NIR and pretreatment. BioRes 2010, 5:2063-2080.

43. Belini UL, Hein PRG, Filho MT, Rodrigues JC, Chaix G: NIR for bagasse content of MDF. BioRes 2011, 6:1816-1829.

44. Inagaki T, Siesler HW, Mitsui K, Tsuchikawa S: Crystal structure of cellulose in wood. Biomacromol 2010, 11:2300-2305.

45. Sreenath HK, Koegel RG, Moldes AB, Jeffries TW, Straub RJ: Ethanol production from alfalfa fiber fractions by saccharification and fermentation. Proc Biochem 2001, 36:1199-1204.

46. Abbi M, Kuhad RC, Singh A: Bioconversion of pentose sugars to ethanol by free and immobilized cells of Candida shehatae NCL-3501: fermentation behaviour. Proc Biochem 1996, 31:555-560.

47. Sanchez G, Pilcher L, Roslander C, Modig T, Galbe M, Liden G: Dilute-acid hydrolysis for fermentation of the Bolivian straw material Paja brava. Bioresour Technol 2004, 93:249-256.

48. Sreenath HK, Jeffries TW: Production of ethanol from wood hydrolyzates by yeasts. Bioresour Technol 2000, 72:253-260.

49. Miller GL: Use of dinitrosalicylic acid reagent for determination of reducing sugar. Anal Chem 1959, 31:426-428.

50. Cadete RM, Melo MA, Dussán KJ, Rodrigues RC, Silva SS, Zilli JE, Vital MJ, Gomes FC, Lachance MA, Rosa CA: Diversity and physiological characterization of D-xylose-fermenting yeasts isolated from the Brazilian amazonian forest. PLoS One 2012, 7:e43135.

51. Parekh SR, YU S, Wayman M: Adaptation of Candida shehatae and Pichia stipitis to wood hydrolysates for increased ethanol production.: Aspen Bibl; 1986:Paper 3623.
52. Gouveia ER, Nascimento RT, Maior AMS, Rocha GJM: Validação de metodologia para a caracterização química de bagaço de cana-deaçúcar. Quim Nova 2009, 32:1500-1503.

53. Scalbert A, Monties B, Janin G: Tannins in wood: comparison of different estimation methods. J Agric Food Chem 1989, 37:1324-1329.

54. Segal L, Creely JJ, Martin AE Jr, Conrad CM: An empirical method for estimating the degree of crystallinity of native cellulose using the X-ray diffractometer. Tex Res J 1962, 29:786-794.

doi:10.1186/1754-6834-6-4

Cite this article as: Chandel et al:: Ultra-structural mapping of sugarcane bagasse after oxalic acid fiber expansion (OAFEX) and ethanol production by Candida shehatae and Saccharomyces cerevisiae. Biotechnology for Biofuels 2013 6:4.

\section{Submit your next manuscript to BioMed Central and take full advantage of:}

- Convenient online submission

- Thorough peer review

- No space constraints or color figure charges

- Immediate publication on acceptance

- Inclusion in PubMed, CAS, Scopus and Google Scholar

- Research which is freely available for redistribution

Submit your manuscript at www.biomedcentral.com/submit
C Biomed Central 